\title{
A Web-based Design for Occupational Safety and Health Capability Maturity Indicator
}

DOI:

10.1016/j.ssci.2019.104516

\section{Document Version}

Accepted author manuscript

Link to publication record in Manchester Research Explorer

\section{Citation for published version (APA):}

Poghosyan, A., Manu, P., Mahamadu, A-M., Akinade, O., Mahdjoubi, L., Gibb, A., \& Behm, M. (2020). A Webbased Design for Occupational Safety and Health Capability Maturity Indicator. Safety Science, 122, [104516]. https://doi.org/10.1016/j.ssci.2019.104516

\section{Published in:}

Safety Science

\section{Citing this paper}

Please note that where the full-text provided on Manchester Research Explorer is the Author Accepted Manuscript or Proof version this may differ from the final Published version. If citing, it is advised that you check and use the publisher's definitive version.

\section{General rights}

Copyright and moral rights for the publications made accessible in the Research Explorer are retained by the authors and/or other copyright owners and it is a condition of accessing publications that users recognise and abide by the legal requirements associated with these rights.

\section{Takedown policy}

If you believe that this document breaches copyright please refer to the University of Manchester's Takedown Procedures [http://man.ac.uk/04Y6Bo] or contact uml.scholarlycommunications@manchester.ac.uk providing relevant details, so we can investigate your claim.

\section{OPEN ACCESS}




\title{
Safety Science
}

\section{A Web-based Design for Occupational Safety and Health Capability Maturity Indicator}

\section{Accepted: $5^{\text {th }}$ October 2019}

DOI: 10.1016/j.ssci.2019.104516

\begin{abstract}
Anush Poghosyan ${ }^{1}$, Patrick Manu ${ }^{1 *}$, Abdul-Majeed Mahamadu ${ }^{2}$, Olugbenga Akinade ${ }^{3}$, Lamine Mahdjoubi ${ }^{2}$, Alistair Gibb ${ }^{4}$, and Michael Behm ${ }^{5}$
\end{abstract}

1 School of Mechanical, Aerospace and Civil Engineering, The University of Manchester, Manchester, United Kingdom.

${ }^{2}$ Faculty of Environment and Technology, University of the West of England, Bristol, United Kingdom.

3 School of Architecture, Civil and Building Engineering, Loughborough University, Loughborough, United Kingdom.

${ }^{4}$ College of Engineering and Technology, East Carolina University, Greenville, North Carolina, USA.

${ }^{5}$ Bristol Business School, University of the West of England, Bristol, United Kingdom.

* Corresponding author

Email: Patrick.Manu@manchester.ac.uk

Telephone: 00441613067572

\section{Declarations of interest}

None

\section{Acknowledgement}

Appreciation is extended to the UK Engineering and Physical Sciences Research Council for providing funding for this research (grant numbers: EP/N033213/1; EP/N033213/1). Appreciation is also extended to the following industry organisations for their in-kind contribution towards the research: Bam Construction Limited, Heathrow Airport, ISG Ltd, Mott MacDonald, Nick Bell Risk Consultancy, GCP Architects, and Safety in Design. 


\begin{abstract}
It has been established that design contributes to the occurrence of occupational injuries and illnesses in the construction sector. This has resulted in the need for designers to implement design for occupational safety and health (DfOSH), which is required by legislation in some countries. Consequently, designers (as individuals or organisations) should seek to mitigate occupational safety and health $(\mathrm{OSH})$ risks through design. In order for design firms to do this effectively, they need to have the capability in respect of implementing DfOSH. However, there is a paucity of empirical studies on DfOSH capability as well as a robust mechanism for ascertaining the DfOSH capability of design firms. Drawing on the capability maturity concept combined with the application of expert group techniques, this study develops a novel web-based DfOSH capability maturity model that enables the assessment of the DfOSH capability of design organisations in the built environment. The model captures $18 \mathrm{DfOSH}$ organisational capability attributes mapped onto five stages of capability maturation which are further contextualised by the incorporation of maturity level indicator examples in order to enable ease of use of the model. Results of the model evaluation confirm the model's usefulness. Design firms could apply the model to self-assess their capability in order to understand the areas of capability deficiency and strength. Client organisations could also use the model as part of pre-qualification arrangements in selecting design firms with the needed DfOSH capability.
\end{abstract}

Keywords: design; design for occupational safety and health; prevention through design; safety in design; capability maturity model; construction.

\title{
1.0 Introduction
}

The International Labour Organisation (ILO), estimates that about four percent of the world's gross domestic product (GDP) is lost due to work-related accidents and diseases (ILO, 2012). The construction sector is one of the highest contributors to work-related accidents and diseases. For instance, in the United Kingdom (UK), over the past decade, consistently the construction sector has accounted for a greater proportion of the number of occupational fatalities, injuries and illnesses (HSE, 2015a). There are over 2 million workers in the UK construction sector (ONS, 2011) and the Health and Safety Executive (HSE) (2015b) estimates that yearly about $3 \%$ of workers suffer from work-related illness and about 3\% sustain an occupational injury resulting in 1.7 million lost working days. The rate of fatal injuries to workers in the construction sector is about 3.5 times the average rate of fatal injuries to workers in all industries, and also the rate of non-fatal injuries in construction is about 1.5 times the average rate in all industries. In terms of occupational illnesses, the prevalence rate of selfreported illness in construction is also higher than the average rate in all industries (HSE, 2015b). In the United States of America (USA), the construction industry accounted for the largest number of fatal injuries (i.e. 991) in 2016 (Bureau of Labor Statistics, 2017). The high social and economic impacts arising from accidents, injuries and illnesses (see Waehrer et al., 2007; Workplace Safety and Health Institute; 2013; HSE, 2015b) has given rise to several efforts to address the poor status of OSH in construction. One of the prominent initiatives to address the poor status of $\mathrm{OSH}$ is 
design for occupational safety and health (DfOSH), also known as "prevention through design", "design for safety, and "safety in design". While there is a growing body of research on DfOSH in construction (see Poghosyan et al., 2018), empirical work on DfOSH capability of design firms (or more broadly organisations with design responsibility) is sparse (Manu et al., 2017).This study thus examines DfOSH capability. In particular it presents the development of a capability maturity model for $\mathrm{DfOSH}$. The next section presents an overview of DfOSH and capability maturity models to provide the underpinning for the development of the DfOSH capability maturity model. This is followed by the research methods, results and discussion. Finally, the concluding remarks and research implications are presented.

\subsection{Literature Review}

\subsection{Design for Occupational Safety and Health (DfOSH)}

DfOSH involves anticipating and eliminating or minimising $\mathrm{OSH}$ hazards and risks in the design process of a building or structure in order to eliminate or minimise the risks of occupational injury and illness to construction and maintenance workers (Schulte et al., 2008). The prominence of DfOSH is rooted in studies which have highlighted design as a contributory factor in the occurrence of construction accidents and injuries (e.g. Behm, 2005; Gibb et al., 2006; Manu et al., 2014). In the study by Behm (2005), undertaken in the USA, $42 \%$ of 224 construction fatality cases were linked to design. In another USA inquiry involving the examination of 27 construction site incidents, design was linked to up to $30 \%$ of the accidents (Behm and Schneller, 2013). The research by Gibb et al. (2006) reported that up to $50 \%$ of 100 construction accident cases that were studied could have been mitigated through a design change. Cooke and Lingard (2011), through an analysis of work-related deaths in the Australian construction industry, also found that $14 \%$ of the cases were linked to design. From these studies, it is evident that design is an important factor in construction accident causation and as a consequence DfOSH is growing in prominence as shown by similar legislation supporting its practice in some countries e.g. in UK, the Construction (Design and Management) (CDM) Regulations 2015; in Australia, the Work Health and Safety Acts and Regulations; in Singapore, the Workplace Safety and Health (Design for Safety) Regulations 2015; and in Ireland, the Safety, Health and Welfare at Work (Construction) Regulations 2013.

$\mathrm{DfOSH}$ requires that designers (as individual professionals or organisations) take into consideration the $\mathrm{OSH}$ implications of their designs decisions during the design stages of built assets. The UK CDM regulations, now in its third iteration (i.e. CDM 2015) after previous versions (i.e. CDM 1994 and CDM 2007) require that designers when preparing or modifying designs, reduce foreseeable risk as far as practicable through their decisions. The CDM 2015 has also introduced a new requirement in respect of the organisational capability of organisations to undertake their operations in a manner that protects workers from OSH injuries and illnesses. Specifically, in the case of design firms, this can be viewed in terms of their capability to implement DfOSH on projects. However, regardless of legislative requirements for DfOSH organisational capability in the CDM 2015 and similar regulations in other countries (e.g. Regulation 
7 of Ireland's Safety, Health and Welfare at Work (Construction) Regulations 2013), the contribution of design to the occurrence of occupational incidents in construction makes it important for design firms to have the capability to implement DfOSH on projects. However, in the growing body of $\mathrm{DfOSH}$ academic literature, empirical work into DfOSH capability of design organisations is sparse. For instance, Öney-Yazıcı and Dulaimi (2015) observed that DfOSH publications have often focussed on: (1) policies and regulations (e.g. Aires et al., 2010); (2) development of measures, procedures, design suggestions, and tools (e.g. Gangolells et al. 2010); and (3) integration of safety into the design process of construction projects (e.g. Weinstein et al., 2005). Poghosyan et al. (2018) through a review of DfOSH literature (reported in journals from 1990 to mid-2017) noted the prevalence of research on issues relating to designer knowledge/awareness and education (i.e. $60.37 \%$ of the 164 articles they reviewed are related to knowledge/awareness and education issues). This gives a hint about the importance of $\mathrm{DfOSH}$ related knowledge and skills to its implementation. Poghosyan et al. (2018), however, noted that although designers may be supportive of DfOSH implementation and may be aware of DfOSH, the level of DfOSH knowledge and education needs to be continuously improved. In view of that researchers have emphasised the need for promotion of DfOSH knowledge acquisition through university courses and training (Behm et al., 2014; López-Arquillos et al., 2015; Goh and Chua, 2016; Toh, et al., 2017). However, in respect of DfOSH capability of design organisations, there is limited empirical research regarding its constituents and the mechanisms/tools by which it can be reliably assessed (Manu et al., 2017; 2019).

\subsection{Tools for DfOSH Implementation}

A thorough review of existing international evidence on $\mathrm{DfOSH}$ in construction from the early 1990s reveals about 40 journal articles (see Table 1) that present the development of tools to facilitate DfOSH implementation. The review shows that the first computer-based tool for DfOSH (i.e. "Design for Construction Safety ToolBox") was developed by Gambatese et al. (1997) to link the design and construction phases in order to improve construction worker safety. Since then, the rapid development of information and communication technologies and their integration into construction industry in the 2000s influenced implementation of complex computer-based tools providing decision support for DfOSH in the construction sector (e.g. Hadikusumo and Rowlinson, 2004, 2012; Cameron and Hare, 2008; Cooke et al., 2008; Nussbaum et al., 2009; Gangolells et al., 2010; Sadeghi et al., 2015). Amongst the functionalities of the above mentioned tools are: a decision support to allow early assessment of ergonomic risks by designers (Nussbaum et al., 2009); a comparison of construction techniques and systems during the design phase and determination of the corresponding levels of safety risk (Gangolells et al., 2010); integration of virtual construction components and processes to identify safety hazards (Hadikusumo and Rowlinson, 2004, 2012); and safety level assessment at the earliest design stages (Sadeghi et al., 2015). However, from the extant literature regarding DfOSH tools in construction it is clear that there is the absence of a tool(s) for assessing/determining the capability of a design organisation to implement DfOSH. This raises an important gap as to how the DfOSH capability of design organisations can be assessed or determined. 


\subsection{Capability Maturity Model}

Originally developed for the domain of software development by the Software Engineering Institute at Carnegie Mellon University, the capability maturity model $(\mathrm{CMM})$ is a reference model of mature practices in a specified discipline/domain/function, used to improve and appraise a group's capability to perform in that discipline/domain/function (Paulk et al., 1993). The CMM is one of the methodological approaches for assessing organisational capability in a domain/function as part of continuous process improvement (Paulk et al., 1993; Sharp et al., 2002; Strutt, et al., 2006; Succar 2009; Maier et al., 2012; Filho and Waterson, 2018). CMM offers a generic framework for continuous process improvement and hence can be adopted industry-wide. Aligned to this, a review of the extant academic literature reveals several studies in construction and other sectors that applied the $\mathrm{CMM}$ to different topic areas including: change management; project, programme and portfolio management; asset management; building information modelling; supply chain management; quality management; and energy management (see Table 2, Maier et al., 2012). In respect of OSH, CMM has also been applied, although not specifically to DfOSH (e.g. the $A C^{2} E$ model developed by Carillion Plc (2013), the safety culture model by HSE (2000) and several other CMMs reported in a literature review by Filho and Waterson (2018)). Filho and Waterson (2018) in their review observe an increase in the use of maturity models to assess safety culture along with variation in the ways maturity models are implemented and documented.

Within topical areas of construction such as building information modelling (BIM), there has been a proliferation of maturity tools including those used by industry stakeholders for organisational BIM capability assessment (see Succar, 2009; Sebastian and Berlo, 2010; McCuen et al., 2012; Mahamadu et al., 2017). For instance, Succar (2009) proposed a BIM tool to assist organisations to assess their capability and to improve their performance, and Sebastian and van Berlo (2010) developed a tool used in the Netherlands for benchmarking the BIM performance of design, engineering and construction firms. The application of CMM in several areas (including $\mathrm{OSH}$ ) as a robust process improvement tool thus supports its application to DfOSH to produce a DfOSH capability maturity model that would provide a means for ascertaining the DfOSH capability of organisations performing design roles in the built environment. A DfOSH capability maturity tool could be beneficial to several built environment stakeholders, particularly: construction clients (and their representatives) who commission construction projects and appoint firms with design responsibilities; design firms (e.g. civil/structural engineering, architectural and building services engineering) who have design responsibilities on projects; contractors, especially those engaged in design and build construction works; and construction OSH consulting firms who provide OSH advisory services regarding DfOSH. The next section presents the research methods applied to develop a DfOSH capability maturity tool for the construction sector. 
Table 1: Studies on tool development for design for occupational safety health in construction (in journals)

\begin{tabular}{|c|c|c|c|c|c|c|}
\hline Author(s) & Year & Journal & Volume & Issue & $\begin{array}{l}\text { Pages/Pages } \\
\text { reference }\end{array}$ & Aim(s)/Objective(s) of Study \\
\hline $\begin{array}{l}\text { S. E. Magnusson, H. Frantzich, } \\
\text { K. Harada }\end{array}$ & 1996 & FSG & 27 & 4 & $305-334$ & $\begin{array}{l}\text { Structuring the procedures of uncertainty analysis and safety checking. A major objective is to } \\
\text { illustrate the various methods and approaches by showing calculations and results for an actual } \\
\text { design problem. }\end{array}$ \\
\hline $\begin{array}{l}\text { J. A. Gambatese, J. Hinze, C. } \\
\text { Haas }\end{array}$ & 1997 & JAE & 3 & 1 & $32-41$ & $\begin{array}{l}\text { Incorporating design suggestions from Construction Industry Institute (CII) into a computer } \\
\text { program, titled "Design For Construction Safety ToolBox," that assists designers in recognizing } \\
\text { project-specific hazards and implementing the design suggestions into a project's design. }\end{array}$ \\
\hline M. A. Hassanain & 1998 & StS & 26 & 1 & $55-62$ & $\begin{array}{l}\text { Identifying the causes of fire accidents in student housing facilities and classifying the factors } \\
\text { that make it a high fire-risk type of facility. }\end{array}$ \\
\hline J. Gambatese, J. Hinze & 1999 & $A C$ & 8 & 6 & $643-649$ & $\begin{array}{l}\text { Searching and developing design suggestions or 'best practices' which could be implemented } \\
\text { in the design phase in order to improve safety during construction. }\end{array}$ \\
\hline M. D. Hansen & 2000 & PC & 45 & 1 & $20-25$ & \\
\hline $\begin{array}{l}\text { B. H. W. Hadikusumo, S. } \\
\text { Rowlinson }\end{array}$ & 2004 & JCEM & 130 & 2 & $281-289$ & $\begin{array}{l}\text { Discussing research in a design-for-safety-process tool, which aims at: (1) capturing safety } \\
\text { knowledge from safety engineers (2) assisting a safety engineer to identify safety hazards in } \\
\text { construction projects; and (3) training inexperienced safety engineers in identifying safety } \\
\text { hazards and the measures required. }\end{array}$ \\
\hline M. Behm & 2005 & SS & 43 & 8 & $589-611$ & $\begin{array}{l}\text { Establishing a link between the design for construction safety concept and construction } \\
\text { fatalities and then determining the extent and magnitude of that link. }\end{array}$ \\
\hline R. Navon, O. Kolton & 2006 & JCEM & 132 & 7 & $733-740$ & Automating fall prevention procedures. \\
\hline D. V. MacCollum & 2006 & PS & 51 & 5 & $26-33$ & $\begin{array}{l}\text { Developing a methodology for identifying and controlling hazards at the time of design through } \\
\text { a case study. }\end{array}$ \\
\hline K. Imriyas, L. S. Pheng, T. A. Lin & 2007 & ASR & 50 & 2 & $149-162$ & $\begin{array}{l}\text { Formulating a methodology for estimating accident risks in building projects and developing a } \\
\text { decision support system (DSS) for automating the above methodology. }\end{array}$ \\
\hline I. Cameron, B. Hare & 2008 & CME & 26 & 9 & $899-909$ & $\begin{array}{l}\text { Introducing eight integrated tools and identifying where and how health and safety (H\&S) } \\
\text { issues can be accommodated within each tool including the identification of practical } \\
\text { considerations. }\end{array}$ \\
\hline
\end{tabular}




\begin{tabular}{|c|c|c|c|c|c|c|}
\hline Author(s) & Year & Journal & Volume & Issue & $\begin{array}{l}\text { Pages/Pages } \\
\text { reference }\end{array}$ & Aim(s)/Objective(s) of Study \\
\hline $\begin{array}{l}\text { T. Cooke, H. Lingard, N. } \\
\text { Blismas, A. Stranieri }\end{array}$ & 2008 & ECAM & 15 & 4 & $336-351$ & $\begin{array}{l}\text { Presenting an innovative information and decision support tool (ToolSHeD) developed to help } \\
\text { construction designers to integrate the management of OSH risk into the design process. }\end{array}$ \\
\hline J. Seo, H. Choi & 2008 & JCEM & 134 & 1 & $72-81$ & $\begin{array}{l}\text { Developing a risk-based safety impact assessment methodology for underground construction } \\
\text { projects in the design phase to consider design for safety. }\end{array}$ \\
\hline $\begin{array}{l}\text { P. G. Kovalchik, R. J. Matetic, A. } \\
\text { K. Smith, S. B. Bealko }\end{array}$ & 2008 & JSR & 39 & 2 & $251-254$ & $\begin{array}{l}\text { Describing the quiet-by-design approach of a noise control using the four functional areas of } \\
\text { PtD, namely Practice, Policy, Research, and Education. }\end{array}$ \\
\hline A. Frijters, P. Swuste & 2008 & SS & 46 & 2 & $272-281$ & $\begin{array}{l}\text { Devising a method that would help designers to choose between alternative building elements } \\
\text { on the basis of safety aspects. }\end{array}$ \\
\hline $\begin{array}{l}\text { M. A. Nussbaum, J. P. } \\
\text { Shewchuk, S. Kim, H. Seol, C. } \\
\text { Guo }\end{array}$ & 2009 & E & 52 & 1 & $87-103$ & $\begin{array}{l}\text { Developing a decision support system for residential construction using panellised walls to } \\
\text { allow panel designers to consider ergonomic risks. }\end{array}$ \\
\hline $\begin{array}{l}\text { R. Rwamamara, H. Norberg, T. } \\
\text { Olofsson, O. Lagerqvist }\end{array}$ & 2010 & $\mathrm{Cl}$ & 10 & 3 & $248-266$ & $\begin{array}{l}\text { Investigating how H\&S gains and improvements of the construction workplace can be made } \\
\text { through the use visualization technologies. }\end{array}$ \\
\hline $\begin{array}{l}\text { M. Gangolells, M. Casals, N. } \\
\text { Forcada, X. Roca, A. Fuertes }\end{array}$ & 2010 & JSR & 41 & 2 & $107-122$ & $\begin{array}{l}\text { Establishing the necessary basis and criteria to quantitatively measure the safety performance } \\
\text { of construction projects. }\end{array}$ \\
\hline $\begin{array}{l}\text { H. Yanga, D. A.S. Chewb, W. } \\
\text { Wuc, Z. Zhouc, Q. Li }\end{array}$ & 2011 & AAP & 48 & & $193-203$ & $\begin{array}{l}\text { Designing and implementing an identification system in construction site safety for proactive } \\
\text { accident prevention. }\end{array}$ \\
\hline $\begin{array}{l}\text { B.H.W. Hadikusumo, S. } \\
\text { Rowlinson }\end{array}$ & 2012 & $A C$ & 11 & 5 & $501-509$ & $\begin{array}{l}\text { Developing a design-for-safety-process tool to help identify safety hazards inherited during the } \\
\text { building construction phase. }\end{array}$ \\
\hline W. Zhou, J. Whyte, R. Sacks & 2012 & $A C$ & 22 & & $102-111$ & $\begin{array}{l}\text { Reviewing existing research on the application of digital technologies in design for construction } \\
\text { safety by bringing together these two strands. }\end{array}$ \\
\hline C. K. Chun, H. Li, M. Skitmore & 2012 & $\mathrm{Cl}$ & 12 & 1 & $29-42$ & $\begin{array}{l}\text { Describing and illustrating a new application involving the use of a multi-dimensional simulation } \\
\text { tool - Construction Virtual Prototyping. }\end{array}$ \\
\hline K. S. Dewlaney, M. Hallowell & 2012 & $\mathrm{CME}$ & 30 & 2 & $165-177$ & $\begin{array}{l}\text { Identifying risk mitigation strategies that reduce the safety risk associated with the design and } \\
\text { construction of high performance sustainable projects. }\end{array}$ \\
\hline
\end{tabular}




\begin{tabular}{|c|c|c|c|c|c|c|}
\hline Author(s) & Year & Journal & Volume & Issue & $\begin{array}{l}\text { Pages/Pages } \\
\text { reference }\end{array}$ & Aim(s)/Objective(s) of Study \\
\hline $\begin{array}{l}\text { M. I. Mohamad, M. A. Nekooie, } \\
\text { A. B. S. Al-Harthy }\end{array}$ & 2012 & JCDC & 17 & 2 & $23-44$ & $\begin{array}{l}\text { Formulating practical procedures for the assessment of structural design changes, identifying } \\
\text { the sources, causes and impacts of design changes on residential reinforced concrete } \\
\text { buildings. }\end{array}$ \\
\hline M. A. Qianlia, G. Wei & 2012 & PE & 45 & & $685-689$ & $\begin{array}{l}\text { Addressing the problems in the fire safety design of a high-rise residential building and } \\
\text { providing solutions to these problems. }\end{array}$ \\
\hline $\begin{array}{l}\text { S. Zhang, J. Teizer, J.-K. Lee, C. } \\
\text { M. Eastman, M. Venugopal }\end{array}$ & 2013 & $\mathrm{AC}$ & 29 & & 183-195 & Developing the rule implementation for fall protection. \\
\hline H. Lingard, R. Wakefield & 2013 & $\begin{array}{l}\text { PICE- } \\
\text { MPL }\end{array}$ & 166 & 5 & $240-248$ & $\begin{array}{l}\text { Describing the voluntary Guide to Best Practice for Safer Construction and examining the } \\
\text { implementation of the design stage component of the guide. }\end{array}$ \\
\hline F. M. Renshaw & 2013 & PS & 58 & 3 & $50-55$ & $\begin{array}{l}\text { Highlighting findings from recent research conducted by National Institute for Occupational } \\
\text { Safety and Health (NIOSH) that led to development of a model PtD program. }\end{array}$ \\
\hline $\begin{array}{l}\text { H. Park, B. J. Meacham, N. A. } \\
\text { Dembsey, M. Goulthorpe }\end{array}$ & 2014 & BRI & 42 & 6 & $696-709$ & $\begin{array}{l}\text { Developing a framework for the incorporation of an improved building fire safety performance } \\
\text { into building design process. }\end{array}$ \\
\hline $\begin{array}{l}\text { J. Qi, R. R. A. Issa, S. Olbina, J. } \\
\text { Hinze }\end{array}$ & 2014 & JCCE & 28 & 5 & A4014008 & Developing PtD tool based on computer software. \\
\hline $\begin{array}{l}\text { S. Mahmoudi, F. Ghasemi, I. } \\
\text { Mohammadfam, E. Soleimani }\end{array}$ & 2014 & SHW & 5 & 3 & $125-130$ & $\begin{array}{l}\text { Delivering a comprehensive framework that enables construction companies to monitor and } \\
\text { improve their performance with respect to OSH issues. }\end{array}$ \\
\hline $\begin{array}{l}\text { V. Dharmapalan, J. A. } \\
\text { Gambatese, J. Fradella, A. M. } \\
\text { Vahed }\end{array}$ & 2015 & JCEM & 141 & 4 & 04014090 & $\begin{array}{l}\text { Identifying the typical building design elements and associated construction activities, giving } \\
\text { quantification of the unit and cumulative risks of the design elements and construction activities } \\
\text { and developing an online design risk-assessment tool. }\end{array}$ \\
\hline J.W. Mroszczyk & 2015 & PS & 60 & 6 & $55-68$ & Presenting an eliminate-plan-prevent-protect strategy to improve construction site safety. \\
\hline D. W. Wilbanks & 2015 & PS & 60 & 4 & $46-51$ & Developing a curriculum model to facilitate hazard analysis \& risk assessment. \\
\hline $\begin{array}{l}\text { A. López-Arquillos, J.C. Rubio- } \\
\text { Romero }\end{array}$ & 2015 & $\mathrm{RC}$ & 14 & & $58-64$ & $\begin{array}{l}\text { Analysing the existing indicators to quantify the levels of OSH; proposing and validating } \\
\text { indicators to measure the PtD in civil engineering projects. }\end{array}$ \\
\hline $\begin{array}{l}\text { L. Sadeghi, L. Mathieu, N. } \\
\text { Tricot, L. Al Bassit }\end{array}$ & 2015 & SS & 80 & & $252-263$ & Measuring human safety when using a system during its design process. \\
\hline
\end{tabular}




\begin{tabular}{|c|c|c|c|c|c|c|}
\hline Author(s) & Year & Journal & Volume & Issue & $\begin{array}{l}\text { Pages/Pages } \\
\text { reference }\end{array}$ & Aim(s)/Objective(s) of Study \\
\hline $\begin{array}{l}\text { S. Zhang, K. Sulankivi, M. } \\
\text { Kiviniemi, I. Romo, C. M. } \\
\text { Eastman, J. Teizer }\end{array}$ & 2015 & SS & 72 & & $31-45$ & $\begin{array}{l}\text { Investigating how potential fall hazards can be identified and eliminated early in the planning } \\
\text { phase of a construction project. }\end{array}$ \\
\hline $\begin{array}{l}\text { J. Weidman, D. Dickerson, C. } \\
\text { Koebel }\end{array}$ & 2015 & W & 52 & 4 & $865-876$ & $\begin{array}{l}\text { Developing a conceptual model to describe the parameters and causal relationships that } \\
\text { influence and predict construction stakeholder "adoption readiness" for PtD technology } \\
\text { innovation. }\end{array}$ \\
\hline J. Teizer & 2016 & $\mathrm{Cl}$ & 16 & 3 & $253-280$ & $\begin{array}{l}\text { Investigating the critical time window for pro-active construction accident prevention and } \\
\text { response. }\end{array}$ \\
\hline $\begin{array}{l}\text { M. Z. Abidin, R. Rusli, A. M. } \\
\text { Shariff }\end{array}$ & 2016 & $\mathrm{PE}$ & 148 & & $1043-1050$ & $\begin{array}{l}\text { Illustrating the use of the TOPSIS-entropy method as a decision-making tool to evaluate the } \\
\text { trade-off of Inherently Safer Design (ISD) alternatives. }\end{array}$ \\
\hline Y.-W. Zhang & 2016 & PE & 135 & & $537-543$ & $\begin{array}{l}\text { Introducing a model to evaluate the economic efficiency of different schemes to make fire } \\
\text { safety investment more reasonable. }\end{array}$ \\
\hline
\end{tabular}

$\underline{\text { Notes }}$

Journals: AAP - Accident Analysis and Prevention; AC - Automation in Construction; ASR - Architectural Science Review; BE - Building and Environment; BRI - Building Research \& Information; CE - Civil Engineering; CIQ - Construction Information Quarterly; CI - Construction Innovation; CME - Construction Management and Economics; E - Ergonomics; ECAM - Engineering, Construction and Architectural Management; FSJ - Fire Safety Journal; JAE - Journal of Architectural Engineering; JCEM - Journal of Construction Engineering and Management; JCDC - Journal of Construction in Developing Countries; JCC - Journal of Computing in Civil Engineering; JSR - Journal of Safety Research; PE - Procedia Engineering; PICE-MPL- Proceedings of ICE Management, Procurement and Law; PS - Professional Safety; RESS - Reliability Engineering and System Safety; RC - Revista de la construcción; SHW - Safety and Health at Work; SS - Safety Science; StS - Structural Survey; W - Work. 
Table 2: Examples of studies on capability maturity model development within construction (in journals)

\begin{tabular}{|c|c|c|c|c|c|c|c|c|c|}
\hline Author(s) & Year & Journal & Volume & Issue & $\begin{array}{l}\text { Pages/Pages } \\
\text { reference }\end{array}$ & $\begin{array}{l}\text { Methods used in } \\
\text { Study }\end{array}$ & Area/Focus & $\begin{array}{l}\text { Number of } \\
\text { maturity } \\
\text { levels }\end{array}$ & Description of levels \\
\hline $\begin{array}{l}\text { M. Sarshar, R. Haigh, M. } \\
\text { Finnemore, G. Aouad, P. } \\
\text { Barrett, D. Baldry, M. } \\
\text { Sexton }\end{array}$ & 2000 & ECAM & 7 & 3 & $241-250$ & $\begin{array}{l}\text { SPICE model } \\
\text { development; } \\
\text { literature review; } \\
\text { expert panels; } \\
\text { questionnaire } \\
\text { survey; case } \\
\text { studies }\end{array}$ & $\begin{array}{l}\text { Capability } \\
\text { maturity model }\end{array}$ & 5 & $\begin{array}{l}\text { Maturity levels: Level 1- Initial; Level } 2 \text { - } \\
\text { Repeatable; Level } 3 \text { - Defined; Level } 4 \text { - } \\
\text { Managed; Level } 5 \text { - Optimized. }\end{array}$ \\
\hline J. S. Goulding, M. Alshawi & 2002 & CME & 20 & 6 & $493-505$ & $\begin{array}{l}\text { CMM } \\
\text { development; } \\
\text { literature review }\end{array}$ & $\begin{array}{l}\text { Information } \\
\text { technology } \\
\text { training in } \\
\text { construction } \\
\text { organisation }\end{array}$ & 6 & $\begin{array}{l}\text { Maturity levels: Phase zero; Phase one; } \\
\text { Phase two; Phase three; Phase four; } \\
\text { Phase five; Phase six. }\end{array}$ \\
\hline D. Nightingale, J. H. Mize & 2002 & IKSM & 3 & 1 & $15-30$ & CMM development & $\begin{array}{l}\text { Capability } \\
\text { Maturity }\end{array}$ & 5 & $\begin{array}{l}\text { Maturity levels: Level 1; Level 2; Level 3; } \\
\text { Level 4; Level 5. }\end{array}$ \\
\hline P.R. Davis, D.H.T. Walker & 2009 & ECAM & 16 & 5 & $475-489$ & $\begin{array}{l}\text { CMM } \\
\text { development; } \\
\text { literature review; } \\
\text { case study }\end{array}$ & Human capital & 5 & $\begin{array}{l}\text { Maturity levels: Inactive Awareness; Pre- } \\
\text { active Initiation; Active Adoption; Pro- } \\
\text { active Acceptance and Adaptation; } \\
\text { Embedded Routinisation and Infusion. }\end{array}$ \\
\hline $\begin{array}{l}\text { P. X. W. Zou, Y. Chen, T.- } \\
\text { Y. Chan }\end{array}$ & 2010 & JCEM & 136 & 8 & $854-863$ & $\begin{array}{l}\text { CMM } \\
\text { development; } \\
\text { questionnaire } \\
\text { survey }\end{array}$ & $\begin{array}{l}\text { Risk } \\
\text { management } \\
\text { capability }\end{array}$ & 4 & $\begin{array}{l}\text { Maturity levels: Level } 1 \text { - Initial and/or Ad } \\
\text { hoc; Level } 2 \text { - Repeatable; Level } 3 \text { - } \\
\text { Managed; Level } 4 \text { - Optimized. }\end{array}$ \\
\hline C. J. Willis, J. H. Rankin & 2010 & JCDC & 15 & 2 & $87-116$ & $\begin{array}{l}\text { Macro maturity } \\
\text { model } \\
\text { development; } \\
\text { expert panel }\end{array}$ & $\begin{array}{l}\text { Macro capability } \\
\text { model }\end{array}$ & 3 & $\begin{array}{l}\text { Maturity levels: Immature; Transitional } \\
\text { Mature; Mature. }\end{array}$ \\
\hline $\begin{array}{l}\text { G. Jia, Y. Chen, X. Xue, J. } \\
\text { Chen, J. Cao, K. Tang }\end{array}$ & 2011 & IJPM & 29 & 7 & $834-845$ & $\begin{array}{l}\text { Capability maturity } \\
\text { model (CMM) } \\
\text { development; case } \\
\text { study }\end{array}$ & $\begin{array}{l}\text { Mega } \\
\text { construction } \\
\text { programmes }\end{array}$ & 4 & $\begin{array}{l}\text { Maturity levels: Standardise; Measure; } \\
\text { Control; Continuously Improve. }\end{array}$ \\
\hline $\begin{array}{l}\text { X. Meng, M. Sun, M. } \\
\text { Jones }\end{array}$ & 2011 & JME & 27 & 2 & $97-105$ & $\begin{array}{l}\text { CMM } \\
\text { development; } \\
\text { expert interviews } \\
\text { case study }\end{array}$ & $\begin{array}{l}\text { Supply chain } \\
\text { relationship }\end{array}$ & 4 & $\begin{array}{l}\text { Maturity levels: Level 1; Level 2; Level 3; } \\
\text { Level } 4 .\end{array}$ \\
\hline $\begin{array}{l}\text { B. Succar, W. Sher, A. } \\
\text { Williams }\end{array}$ & 2012 & AEDM & 8 & 2 & $120-142$ & $\begin{array}{l}\text { Maturity index } \\
\text { development; } \\
\text { literature review }\end{array}$ & $\begin{array}{l}\text { Building } \\
\text { information } \\
\text { modelling (BIM) }\end{array}$ & 5 & $\begin{array}{l}\text { Maturity levels: Initial/Ad Hoc; Defined, } \\
\text { Managed, Integrated; Optimised. }\end{array}$ \\
\hline
\end{tabular}




\begin{tabular}{|c|c|c|c|c|c|c|c|c|c|}
\hline T. Madritsch, M. Ebinger & 2012 & BEPAM & 1 & 2 & $111-121$ & $\begin{array}{l}\text { Built environment } \\
\text { management } \\
\text { model } \\
\text { development; } \\
\text { survey }\end{array}$ & $\begin{array}{l}\text { Built } \\
\text { environment } \\
\text { managment } \\
\text { maturity }\end{array}$ & 5 & $\begin{array}{l}\text { Maturity levels: Level 1: Ad Hoc Business } \\
\text { Processes; Level 2: Repeatable Business } \\
\text { Processes; Level 3: Defined Business } \\
\text { Processes; Level 4: Measured Business } \\
\text { Processes; Level 5: Self-Optimising } \\
\text { Processes. }\end{array}$ \\
\hline C. J. Willis, J. H. Rankin & 2012 & IJPPM & 61 & 4 & $382-402$ & $\begin{array}{l}\text { Macro maturity } \\
\text { model } \\
\text { development; } \\
\text { literature review; } \\
\text { Case study }\end{array}$ & $\begin{array}{l}\text { Macro maturity } \\
\text { model }\end{array}$ & 3 & $\begin{array}{l}\text { Maturity levels: Capability } 1 \text {; Capability 2; } \\
\text { Capability } 3 .\end{array}$ \\
\hline $\begin{array}{l}\text { C. Liang, W. Lu, S. } \\
\text { Rowlinson, X. Zhang }\end{array}$ & 2016 & JCEM & 142 & 11 & $1--1$ & $\begin{array}{l}\text { BIM maturity } \\
\text { model } \\
\text { development; } \\
\text { expert panel }\end{array}$ & BIM & 4 & $\begin{array}{l}\text { Maturity levels: Stage 0; Stage 1; Stage 2; } \\
\text { Stage3; Stage } 4 .\end{array}$ \\
\hline $\begin{array}{l}\text { C. Langston, A. N. } \\
\text { Ghanbaripour }\end{array}$ & 2016 & CEB & 16 & 4 & $68-85$ & $\begin{array}{l}\text { CMM } \\
\text { development; lit. } \\
\text { review; case study }\end{array}$ & $\begin{array}{l}\text { Organisational } \\
\text { maturity } \\
\text { modelling }\end{array}$ & 4 & $\begin{array}{l}\text { Maturity levels: 1. Plan: Establish targets; } \\
\text { 2. Do: Measure outcomes; } 3 \text {. Check: } \\
\text { Assess performance; } 4 \text {. Act: Enhance } \\
\text { protocols. }\end{array}$ \\
\hline
\end{tabular}

Journals: AEDM - Architectural Engineering and Design Management; BEPAM - Built Environment Project and Asset Management; CEB - Construction Economics and Building; CME - Construction Management and Economics; ECAM - Engineering, Construction and Architectural Management; IJPM - International Journal of Project Management; IJPPM - International Journal of Productivity and Performance Management; IKSM - Information Knowledge Systems management; JCEM - Journal of Construction Engineering and Management; JCDC - Journal of Construction in Developing Countries; JME - Journal of Management in Engineering. 


\subsection{Research Method}

The development of a CMM is reliant on the identification of key capability attributes (referred to as key process areas) within the relevant function/domain (Paulk et al., 1993), which in the case of this inquiry is DfOSH. The capability attributes refer to activities, competencies or resources that are required or performed to achieve a set of goals (Curtis et al., 1995). They broadly include processes, people, policy, systems and resources required to execute relevant functions (Paulk et al., 1993; Curtis et al., 1995; Succar, 2009). The capability attributes are then mapped onto distinct stages of maturation referred to as maturity levels (Meng et al., 2011; Maier et al., 2012). The maturity levels and capability attributes together then constitute a two-way capability maturity grid where the capability attributes represent one axis and the maturity levels represent the other axis. In order therefore to develop a DfOSH capability maturity model, it is important to establish: (1) the key process areas (i.e. the DfOSH capability attributes); and (2) the maturity levels (Maier et al., 2012). Additionally, it is important to establish (3) the weightings of the capability attributes, as the attributes could have different weights of importance. This third requirement is commonly overlooked in existing CMMs (e.g. Filho et al., 2010; Meng et al., 2011; Computer Integrated Construction Research Program, 2013; Kang et al., 2015; Langston and Ghanbaripour, 2016; Liang et al., 2016) and could therefore result in CMMs generating misleading results. The methodological process undertaken consisted of four interrelated stages - data collection, model development, web-based system development and system testing. The data collection stage entailed expert focus group discussion, literature review and Delphi technique together with application of voting analytic hierarchy process. Results of the data collection stage determined the three main features of the DfOSH CMM (i.e. DfOSH capability attribute, maturity levels and attribute weights) in the model development stage. Following the model development stage, the model was further developed into a web-based system, which was subsequently evaluated by experts. Figure 1 schematically presents the methodological process followed in this study.

\subsection{Determining the DfOSH Capability Attributes and their Weights}

Maier et al. (2012) noted that selecting key process areas is one of the difficult aspects of developing a maturity grid. Additionally, they noted that the key process areas can be derived from: (1) the grid originator's experience and reference to established knowledge in the relevant domain; and (2) a panel of experts in the domain, especially where there is limited prior literature about the domain. In this study, a panel of construction industry experts was used due to the limited empirical work regarding DfOSH capability. As such, three iterations of expert focus group discussions (FGDs) were held with industry experts to elicit (through brainstorming) the attributes that determine DfOSH capability of a design organisation. The suitability of the FGD approach is also confirmed by its use in other domains (e.g. BIM) to elicit key requirements (from stakeholders) for tool development (e.g. Akinade et al. 2017; 2018).

In order to select suitably qualified and experienced experts in the domain of DfOSH, the guidance of Hallowell and Gambatese (2010) regarding the criteria for selecting experts (e.g. a professional with knowledge in the subject of inquiry, and a minimum 
of five years of experience in a role relevant to the research subject) and minimum number of experts (e.g. the panel of 8-12 experts) was followed. Consequently, a total of eight experts were engaged in the FGDs. Detailed information about the experts (e.g. years of experience in professional role and in construction) is provided in Table 3. The participants of the FGDs were engaged in brainstorming and review sessions, which were aimed at identifying and refining the capability attributes. Each FGD session took about two hours and they span over a 10 month duration. From the brainstorming and reviews, $18 \mathrm{DfOSH}$ capability attributes were identified. The 18 attributes were subsequently clustered, based on their relatedness, into six thematic areas of DfOSH organisational capability. The six thematic groups are: strategy; competence; corporate experience; infrastructure; systems; and collaboration. One of the 18 attributes (i.e. "corporate experience") constituted a category of its own, as it could not be rationally clustered with other attributes. Additionally, the FGD experts suggested examples of maturity indicators (i.e. items that could evidence maturity) for the DfOSH capability attributes.

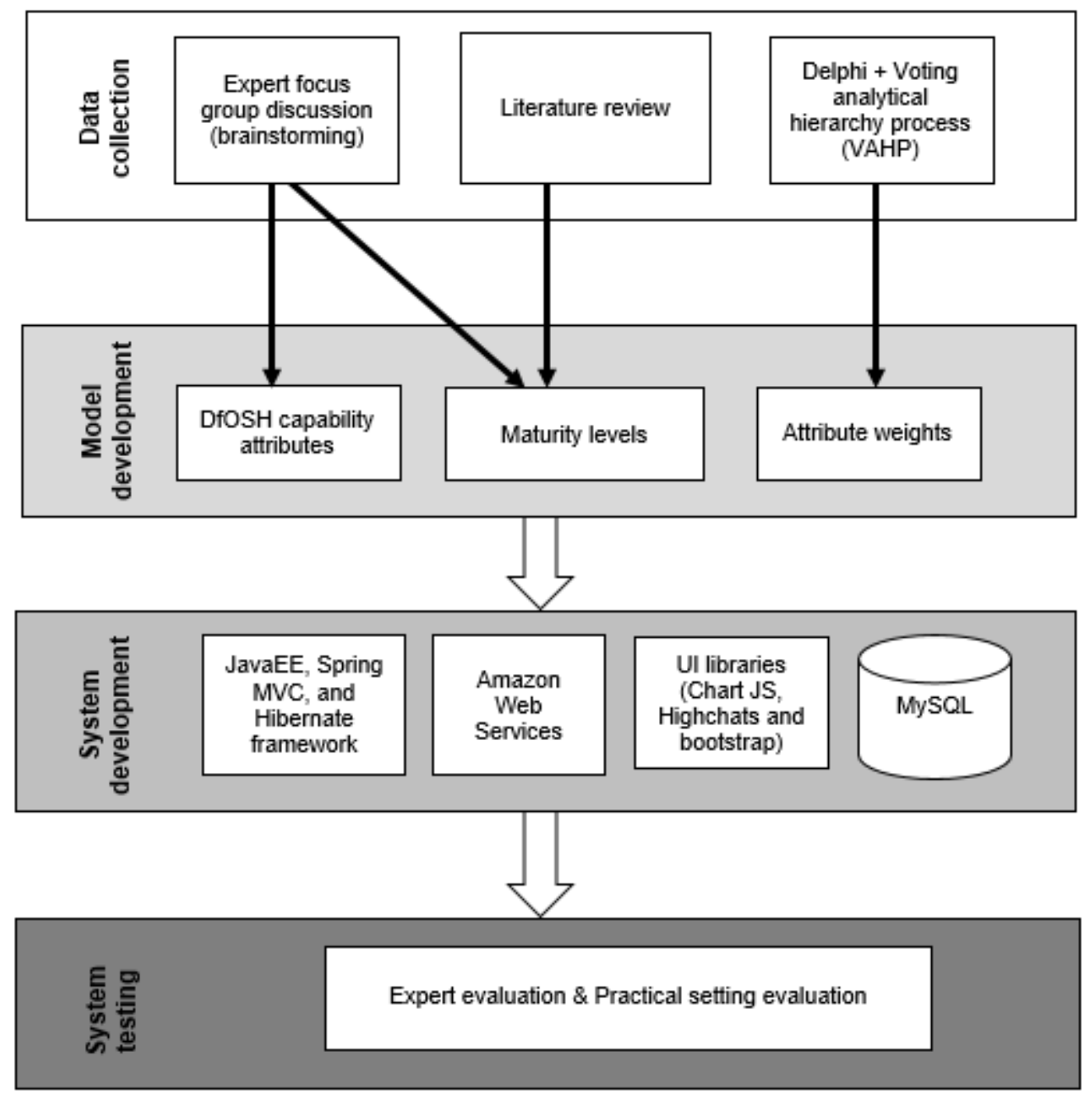

Figure 1: Methodological process for the study 
Table 3: Focus group discussion experts.

\begin{tabular}{l|l|l|l}
\hline Professional role & \multicolumn{1}{|c|}{$\begin{array}{c}\text { Experience in } \\
\text { professional role }\end{array}$} & \multicolumn{1}{|c}{$\begin{array}{c}\text { Experience in } \\
\text { construction }\end{array}$} & \multicolumn{1}{|c}{$\begin{array}{c}\text { Professional body } \\
\text { affiliation/qualifications }\end{array}$} \\
\hline Senior design manager & 12 years & 30 years & CIOB \\
\hline Architect & 31 years as architect & 31 years as architect & RIBA \\
\hline OSH professional & $\begin{array}{l}5 \text { years in current role, } \\
7 \text { years as safety } \\
\text { professional, } 20 \text { years } \\
\text { as design manager. }\end{array}$ & 17 years & IOSH \\
\hline OSH consultant & 10 years & $\begin{array}{l}15 \text { years (including } \\
\text { facilities management) }\end{array}$ & IOSH, IIRSM \\
\hline $\begin{array}{l}\text { Civil/structural engineer and CDM } \\
\text { specialist }\end{array}$ & 28 years & 28 years & ICE, IStructE, APS \\
\hline $\begin{array}{l}\text { Civil engineer and OSH } \\
\text { professional }\end{array}$ & 27 years in OHS & 40 years & ICE, IOSH. \\
\hline Senior quantity surveyor & 20 years & 28 years & RICS \\
\hline Project manager & $\begin{array}{l}10 \text { years as quantity } \\
\text { surveyor and } 20 \text { years } \\
\text { as project manager }\end{array}$ & 33 years & RICS, APM \\
\hline
\end{tabular}

Notes:

APS = Association for Project Safety; APM = Association for Project Management CDM = Construction Design and

Management Regulations; CIOB = Chartered Institute of Building; ICE = Institution of Civil Engineers; IIRSM = International Institute of Risk and Safety Management; IOSH = The Institution of Occupational Safety and Health; IStructE = Institution of Structural Engineers; OSH = Occupational Safety and Health; RIBA = Royal Institute of British Architects; RICS = Royal Institution of Chartered Surveyors.

Following the identification phase, the 18 attributes and their associated six thematic categories were taken forward into three rounds of Delphi expert survey and the application of voting analytic hierarchy process (VAHP) in order to identify the relative priorities (weights) of the attributes. The combined application of Delphi technique and VAHP (a multi-criteria decision making method) was due to their suitability for the identification and prioritisation of multiple competing factors (Liu and Hai, 2005; HadiVencheh and Niazi-Motlagh, 2011; Ameyaw et al., 2016; Austin et al., 2016). This research procedure was undertaken to enable the computation of a DfOSH capability maturity score taking into account the weights of the DfOSH capability attributes. Like the expert FGDs, the Delphi experts were selected based on the guidance of Hallowell and Gambatese (2010) regarding the criteria for selecting experts. The Delphi surveys involved 32 experts (in round 1), 30 experts (in round 2), and 28 experts (in round 3 ). A detailed account of the application of the expert FGDs, the Delphi surveys and VAHP by the researchers is reported in Manu et al. (2019). Tables 4 and 5 summarise the main outcomes of the FGDs, Delphi surveys and VAHP. Table 4 shows the $18 \mathrm{DfOSH}$ capability attributes and the six thematic categories. Table 5 shows the weights for the capability attributes and the thematic categories. The following sections explain how the information in Tables 4 and 5 were taken forward by the researchers in developing the DfOSH capability maturity model. 
Table 4: DfOSH capability attributes and thematic categories

\begin{tabular}{l|l}
\hline Thematic category & Attributes
\end{tabular}

DfOSH skills of design staff.

DfOSH skills of design staff.

Competence i.e. the competence of organisation's design staff in

DfOSH experience of design staff.

respect of DfOSH.

Access of design staff to in-house or external competent $\mathrm{OSH}$, construction/constructability and maintainability advice.

Clear definition of roles for design staff at various levels as well as the recruitment of design staff into the appropriate roles.

DfOSH continuous professional development (CPD) training for design staff.

Organisation's policy in relation to DfOSH.

Strategy i.e. the consideration of DfOSH in organisation's vision as well as the top management support for DfOSH.

\section{Organisation's top management commitment to DfOSH.}

DfOSH research and innovation i.e. organisation's investment into, conduct of, or exploitation of existing research to enhance $\mathrm{DfOSH}$, as well as organisation's ability to be creative in implementing DfOSH.

\section{${ }^{\mathrm{a}}$ Corporate experience}

Systems i.e. organisation's systems, processes and procedures required for DfOSH.

Corporate experience i.e. organisation's experience in implementing DfOSH on projects.

Design quality management i.e. systems, processes and procedures for design quality review to capture and rectify errors and to ensure conformance of design to proposed DfOSH solutions.

Design risk management i.e. systems, processes and procedures for identification and mitigation of OSH hazards in design as part of design workflow.

Project review i.e. systems, processes and procedures for capturing lessons learnt in order to facilitate future improvements.

Systems, processes, and procedures for ensuring appointment of competent outsourced/subcontracted designers/consultants.

Physical work resources i.e. conducive workstation, workspace/workplace environment, and equipment/materials that support design and $\mathrm{DfOSH}$.

Infrastructure i.e. organisation's physical, information and communication technology (ICT) resources required for $\mathrm{DfOSH}$.

Information and communication technology (ICT) resources i.e. computing and ICT facilities (including hardware and software) that support DfOSH and communication or sharing of design information.

Intra-organisational collaboration i.e. the ability of various design units/sections/departments within organisation to collaborate to implement DfOSH on projects.

Collaboration

Inter-organisational collaboration i.e. the ability of design firm (as a unit) to collaborate with other organisations on a project to implement DfOSH.

a "Corporate experience" is a stand-alone attribute that also constituted its own thematic category.

Source: Adapted from Manu et al. (2019) 
Table 5. Weights of the DfOSH capability attributes and thematic categories

\begin{tabular}{|c|c|c|}
\hline Thematic category/attributes & Within category weight & Global weight \\
\hline \multicolumn{3}{|l|}{ Six thematic category of attributes } \\
\hline Competence & 0.3493 & \\
\hline Strategy & 0.1774 & \\
\hline${ }^{a}$ Corporate Experience & 0.1733 & ${ }^{\mathrm{a}} 0.1733$ \\
\hline Systems & 0.1091 & \\
\hline Infrastructure & 0.0722 & \\
\hline Collaboration & 0.1187 & \\
\hline \multicolumn{3}{|l|}{ Competence category attributes } \\
\hline DfOSH skills of design staff. & 0.2123 & \\
\hline DfOSH knowledge of design staff. & 0.2366 & 0.0826 \\
\hline DfOSH experience of design staff. & 0.2525 & 0.0882 \\
\hline $\begin{array}{l}\text { Access of design staff to in-house or external competent OSH, construction/constructability and maintainability } \\
\text { advice. }\end{array}$ & 0.1027 & 0.0359 \\
\hline $\begin{array}{l}\text { Clear definition of roles for design staff at various levels as well as the recruitment of design staff into the } \\
\text { appropriate roles. }\end{array}$ & 0.1019 & 0.0356 \\
\hline DfOSH continuous professional development (CPD) training for design staff. & 0.0939 & 0.0328 \\
\hline \multicolumn{3}{|l|}{ Systems category attributes } \\
\hline Design quality management & 0.2157 & 0.0235 \\
\hline Design risk management & 0.434 & 0.0473 \\
\hline Project review & 0.2297 & 0.0251 \\
\hline Outsourcing of designers/consultants & 0.1206 & 0.0132 \\
\hline \multicolumn{3}{|l|}{ Strategy category attributes } \\
\hline Organisation's policy in relation to DfOSH. & 0.2567 & 0.0455 \\
\hline Organisation's top management commitment to DfOSH. & 0.4985 & 0.0884 \\
\hline DfOSH research and innovation & 0.2448 & 0.0434 \\
\hline \multicolumn{3}{|l|}{ Infrastructure category attributes } \\
\hline Physical work resources & 0.5349 & 0.0386 \\
\hline
\end{tabular}


Collaboration category attributes

Intra-organisational collaboration Inter-organisational collaboration 


\subsection{Formulating the Maturity Levels}

In general, maturity models consist of formulated maturity levels that can assess the completeness of the analysed objects (e.g. organisations or processes) by applying different sets of multi-dimensional criteria (key attributes) that characterise these objects (Filho and Waterson, 2018). Maturity as used in this study refers to the evolutionary progress in demonstrating a particular capability (Maier et al., 2012; Proença and Borbinha, 2016), which is the implementation of DfOSH by a design organisation. While varying numbers of maturity levels have been used in the extant capability maturity grids (e.g. four levels and five levels (Maier et al., 2012; Filho and Waterson, 2018)), five maturity levels is the most common (see Maier et al., 2012; Filho and Waterson, 2018), in line with the original capability maturity model by Paulk et al. (1993) in which five levels were used. For instance, a systematic review by Filho and Waterson (2018) on safety culture and maturity models revealed that five levels of maturity was used in all the publications that were reviewed. Similarly, in this study, five maturity levels were adopted, with level 1 being the lowest maturity level and level 5 being the highest maturity level. The concept of the capability maturity model is such that progression to or attainment of a higher maturity level is pre-conditioned on the attainment of lower maturity levels so that in order for an organisation to be at maturity level 5 in a capability attribute it should have already met the requirements for the lower levels.

Formulating the maturity levels for each key process area is a very important step in the development of a capability maturity grid. In this regard, Maier et al. (2012) noted from their review of capability maturity models that formulating maturity levels involves: (1) using a top-down or bottom-up approach; (2) consideration of the information source; and (3) consideration of the formulation mechanism. In the top-down approach, maturity level definitions are written before measures are developed to fit the definitions, while in the bottom-up approach the measures are determined first, before definitions are written to reflect the measures (Maier et al., 2012). In the topdown approach, the emphasis is thus firstly on what represents the maturity of process (e.g. safety management process), before how it can be measured (Maier et al., 2012). A top-down approach is most appropriate if the field is relatively new (Maier et al., 2012), hence it was adopted in this study due to the sparse empirical work on DfOSH capability. To define maturity levels in each key process area, it is important to establish the underlying notion of the maturity and to do that several information sources can be useful e.g. existing literature relating to the key process areas, feedback from intended users of the maturity grid, and by reviewing and comparing practices of several organisations (Maier et al., 2012). In this study, existing capability maturity models and best practice guides on topics that are related to each of the DfOSH capability attributes (e.g. Constructing Excellence (2004) best practice guide on effective teamwork and the risk management maturity model $\left(\mathrm{RM}^{3}\right)$ by the Office of Road and Rail and Health and Safety Laboratory (2017)) were reviewed in addition to the maturity indicators suggested by the FGD experts in order to obtain an understanding of what represents maturity in each of the DfOSH capability attributes. This understanding informed the underlying notion of maturity which was then used in formulating the five maturity level descriptors for each of the $18 \mathrm{DfOSH}$ capability attributes. Regarding the formulation mechanism for the maturity level descriptors, in 
line with the suggestion by Maier et al. (2012), in the first instance, the descriptors for the maturity levels at the extreme ends (i.e. level 1 , being the lowest, and level 5 being the highest) were formulated (based on the underlying notion) such that level 1 represented no or very low maturity and level 5 represented the highest level of maturity which is also depicted by regular reviews within the capability attribute in order to ensure continuous improvement. Secondly, the mid-range maturity level descriptors (i.e. from level 2 to level 4) were deduced from the underlying notion and formulated accordingly.

After formulating maturity level descriptors for levels 1-5 for each attribute, maturity level indicator examples were also formulated to accompany each descriptor. The maturity level indicator examples are practical scenarios that depict attainment of a maturity level for a specific attribute. The purpose of including maturity level indicator examples was to enable users to easily understand maturity level descriptors and to also signpost possible real scenarios that would make undertaking a DfOSH capability assessment easy. For the purpose of illustration, an excerpt of the eventual DfOSH capability maturity model is presented in the results section of this paper.

\subsection{Maturity Level Scoring}

Generally, a CMM can be represented as a collection of attributes $\left\{A_{i}\right\}$ with $n$ elements, where $n$ is the number of proposed attributes. In the model each attribute $A_{i}$ can be given a weight, which in this study was empirically derived through the application of Delphi technique and VAHP. Weights are denoted as $w$, where $1 \leq i \leq=n$. The goal is to score each attribute against a scale of $m$ maturity levels. In the model the capability score for $A_{i}$ is denoted as $C S_{i}=j$, where $1 \leq j \leq m$.

Literature shows two most commonly adopted methods for calculating scores for CMMs (Willis and Rankin, 2012; Pane and Sarong, 2015; Liang et al. (2016).

Method 1(Pane and Sarong, 2015): This method proposes to start with calculating the maximum possible maturity score (MS) by applying the following formula:

$$
\mathrm{MS}=\sum_{i=1}^{n} w_{i}{ }^{*} m
$$

where $w_{i}$ is the weight of Attribute $A_{i}$ and $m$ is the number of maturity levels in the CMM. Then the total maturity score $\mathrm{MS}_{\text {total }}$ can be calculated as

$$
M S_{\text {total }}=\sum_{i=1}^{n} w_{i}{ }^{*} C S_{i} \text {. }
$$

It is then advised to look at the ratio of total score and maximum possible total score and pick $m$ intervals in the range $[0,1]$ or alternatively percentages can also be considered.

Method 2 (Willis and Rankin, 2012; Liang et al., 2016): This method proposes the use of empirically derived sub-attribute weightings in the category to derive the score for each attribute $A_{\mathrm{i}}$. Let us assume that each sub-attribute has been assigned a weight $W_{\text {sub }}$ and score $\mathrm{CS}_{\text {sub }}$ (capability score).

The maturity score of each sub attribute is MSsubAttr $=\mathrm{CSS}_{\text {subAttr }}{ }^{*} W_{\text {sub }}$. 
The maturity score of each attribute $M S_{\text {Attr }}=\sum\left(M_{\text {SubAtrr }}\right)^{*} W_{\text {Attr }}$

Total maturity score $M S=\sum M S_{\text {Attr }}$.

Again, it is advised to look at the ratio of total score and maximum possible total score and pick $m$ intervals in the range $[0,1]$ or alternatively percentages can be considered.

\subsubsection{Total Maturity Scoring for DfOSH Capability Maturity}

DfOSH capability maturity model (CMM) consists of five formulated maturity levels and is represented as a collection of 18 attributes $\left\{A_{i}\right\}$. Let us assume each attribute $A_{i}$ has an assigned weight $w_{i}$ (shown by the global weight in Table 5 ) where $1 \leq i \leq 18$ such that $\sum_{i=1}^{18} w_{i}=1$.

While CMMs are often rigid in their scoring scheme, the scoring scheme of DfOSH $\mathrm{CMM}$ was designed to allow for some user flexibility such that a user performing an assessment can choose whether an organisation being assessed attains a maturity level completely or partly for each attribute. This flexibility in the scoring scheme was deemed necessary as in reality, there could be instances where an assessor of an organisation's maturity in respect of an attribute may be of the view that the maturity level attained by the organisation does not precisely fall in one of the five distinct maturity levels, but is partly reflected by the descriptor of a maturity level (e.g. is partly at level 3 ) or that the maturity level falls at the boundary of two adjacent levels (e.g. between level 3 and 4). The scoring mechanism for DfOSH capability maturity thus allowed for three possible scoring scenarios as explained below:

1. The organisation being assessed completely attains maturity level $j$ for attribute $A_{i}$. In this case the capability score for the attribute $A_{i}$ is

$$
\mathrm{CS}_{\mathrm{i}}=j,(1 \leq j \leq m) \text {. }
$$

For example, if "completely attains" level 3 is selected for attribute $A_{i}$, the capability score for this attribute is 3 .

2. The organisation being assessed partly attains maturity level $j$ for attribute $A_{i}$. In this case the capability score for the attribute is given by:

$$
C S_{i}=(2 * j-1) / 2,(1<j \leq m) \text {. }
$$

For example, if "partly attains" level 3 is selected for attribute $A_{i}$, the capability score for this attribute is calculated as $\mathrm{CS}_{i}=\left(2^{\star} 3-1\right) / 2=2.5$.

3. The organisation being assessed straddles the boundary of two adjacent maturity levels for attribute $A_{i}: j-1$ and $j$. In this case the capability score for the attribute is given by:

$$
\mathrm{CS}_{\mathrm{i}}=(j-1+j) / 2=(2 * j-1) / 2,(1<j \leq m) \text {. }
$$

For example, if the maturity level of attribute $A_{i}$ is selected as "partly attains" levels 3 and 4 , the capability score for the attribute is $C S_{i}=\left(2^{*} 4-1\right) / 2=3.5$.

It is worth noting that since in the DfOSH CMM the maturity level 1 represents "no" or "very low" maturity, it was assumed that maturity level 1 can only be attained fully i.e. 
the scoring scheme does not allow maturity level 1 being partly attained as it would be meaningless in the light of the maturity level 1 descriptors.

Total capability maturity score can then be calculated as $\sum_{i=1}^{n} w_{i} \mathrm{CS}_{\mathrm{i}}$. The minimum total capability maturity score that can be achieved is 1 and the maximum total capability maturity score that can be achieved is 5 . Figure 2 presents the pseudocode of the algorithm implemented to calculate total maturity score.

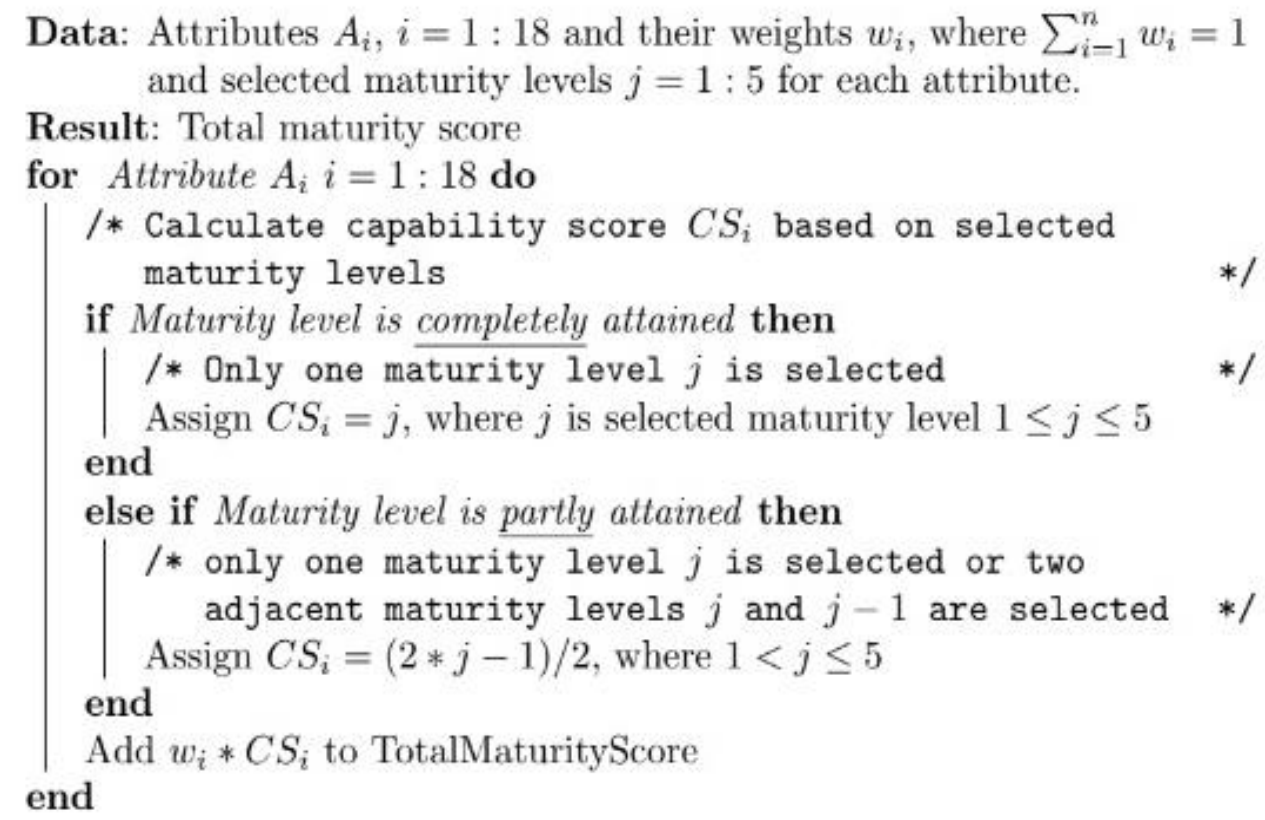

Figure 2: Computation of total maturity level score

\subsubsection{Category Maturity Level Scoring}

Aside the computation of total maturity score, DfOSH CMM was designed to enable maturity level scoring by category for the six thematic categories (shown in Table 5). Thus a maturity score can be obtained, for example for the "Systems" category within which are four attributes (i.e. design quality management, design risk management, project review, and outsourcing of designers/consultants). Maturity level scoring by category was facilitated by the derived attribute weights $w_{c}$ i relative to a category an attribute belongs to (shown by the within category weight in Table 5). The sum of weights $\sum w c_{i}=1$, where the attribute $\mathrm{A}_{\text {ic }}$ belongs to category $\mathrm{C}$. The capability score $\mathrm{CS}_{\mathrm{i}}$ for attribute $\mathrm{A}_{\mathrm{ic}}$ is calculated the same way as described in previous section. The category maturity score for a category $\mathrm{C}$ can then be calculated as $\sum w c_{i} * \mathrm{CS}_{\mathrm{i}}$, where Aic belongs to category $\mathrm{C}$.

\subsection{System development and testing}

The DfOSH CMM (comprising the attributes, attribute weights, maturity level descriptors, maturity level indicator examples, and the scoring scheme described in the previous sections) was implemented as a web-based assessment tool hosted on the Amazon Web Services (AWS) Cloud i.e. users can access the tool on the internet 
through browsers (e.g. Internet Explorer, Chrome and Safari). The tool was named, "Design for Occupational Safety and Health Capability Maturity Indicator (DfOSHCMI)". The DfOSH-CMI tool employs Model-View-Controller (MVC) Architecture and apart from generating scores from DfOSH capability assessments it provides several other useful functionalities such as user management, form generation, form validation, and database access.

DfOSH-CMI is deployed on Apache Tomcat v7.0 web server. It is implemented using programming language Java (Java JDK 1.8) and adopts Java, Spring MVC framework architecture. Hibernate framework is used to map the object-oriented domain model to MySQL database. Jquery2.1, Chart.js, Highcharts and Bootstrap open source libraries were used for the graphical user interface development of DfOSH-CMI.

\subsection{System Architecture}

The system architecture for DfOSH-CMI is based on MVC design pattern framework. MVC is an architectural software design pattern and engineering concept first introduced by Reenskaug and Skaar (1989). Effective use of MVC isolates business logic from user interface which results in highly scalable applications (Deacon, 2009). That is, this software design pattern aims to divide a web application into three separate logical components (Model, View and Controller). The Model component is responsible for the implementation of business logic and data access; the Controller component is responsible for user interaction, processing, validating, responding to user inputs and manipulating the Model as requested by user; and the View component renders the results to the user browser.

\subsection{Model-View-Controller Interaction Example on DfOSH-CMI tool}

Figure 3 illustrates interactions between user, view, controller, model and data storage as adopted by DfOSH-CMI tool. For example, an authorised user (i.e. user with valid login details) completes an assessment form (which is based on the DfOSH maturity grid and scoring scheme) for a new capability assessment and clicks "submit" button. By this action, the user sends a request by graphical user interface (View component). The view sends the input data for processing to the controller. The controller validates the input and sends commands to the model to create a new DfOSH capability assessment document. The model stores all required data and notifies the controller. The view generates new outputs based on the updates from controller and the model. If after successfully completing an assessment a user clicks on "View results", the corresponding action request is then sent to the controller. The controller queries the model to get the data from the corresponding DfOSH capability assessment. Once it has all the data from the model it runs the algorithms responsible for total maturity level scoring and category maturity level scoring. The scores are passed to the view, which renders data as charts and displays results to the user. 


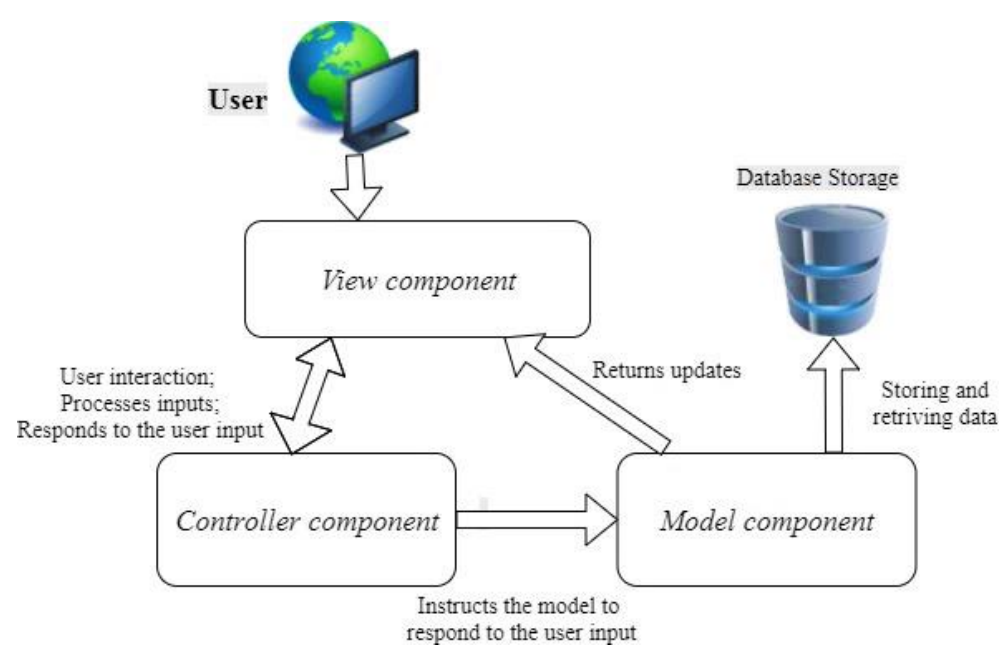

Figure 3: DfOSH-CMI tool system architecture

\subsection{Workflow and Assessment Page of DfOSH-CMI tool}

Figure 4 below presents the typical workflow of DfOSH-CMI tool for the users. Figure 5 , which is a display of a section of the DfOSH-CMI assessment form/page, gives an illustration of attributes, the five maturity levels, the maturity level descriptors and their accompanying indicator examples (which appear as a pop-up display when the cursor hovers over it).

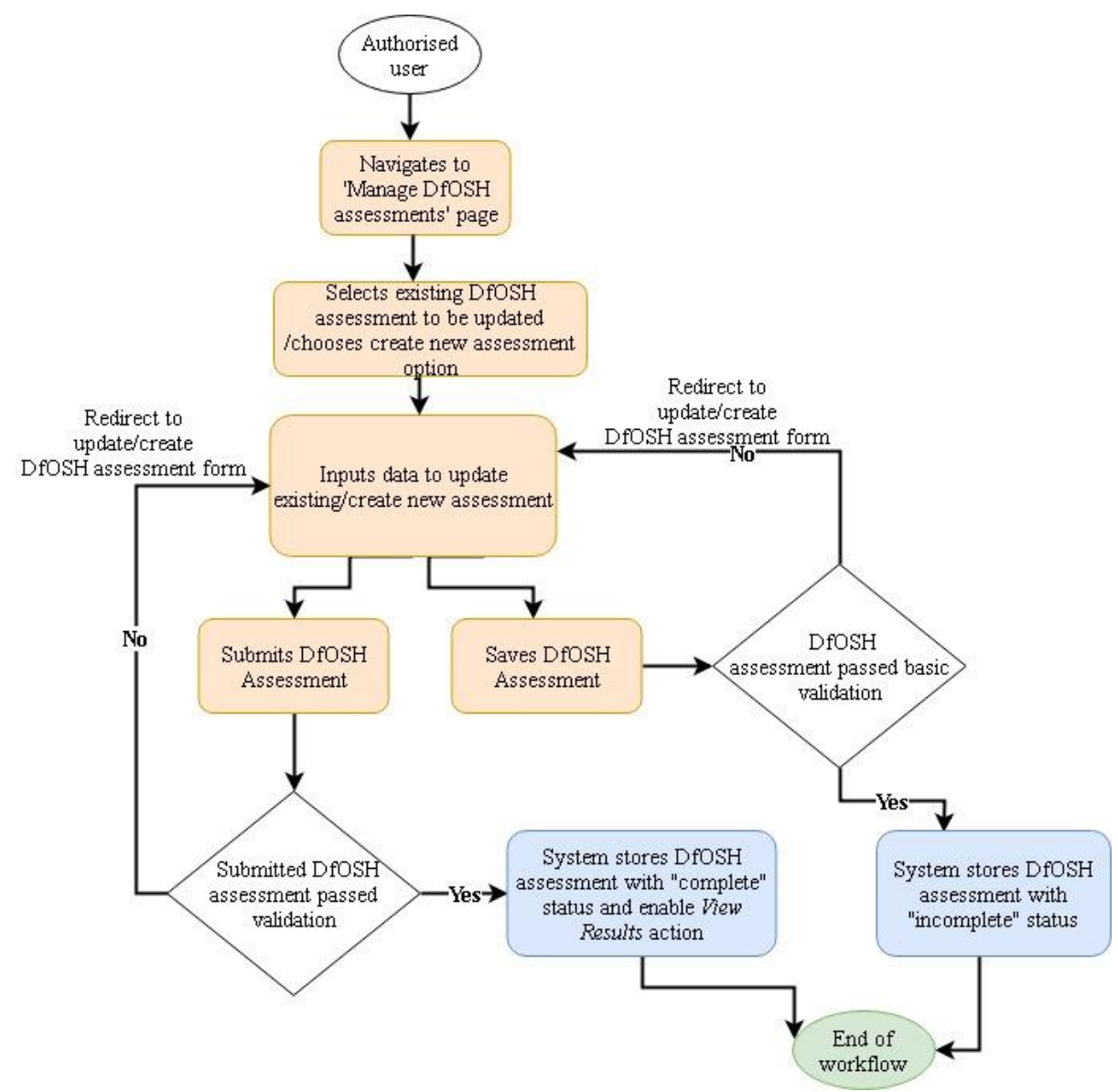

Figure 4: DfOSH-CMI Workflow 

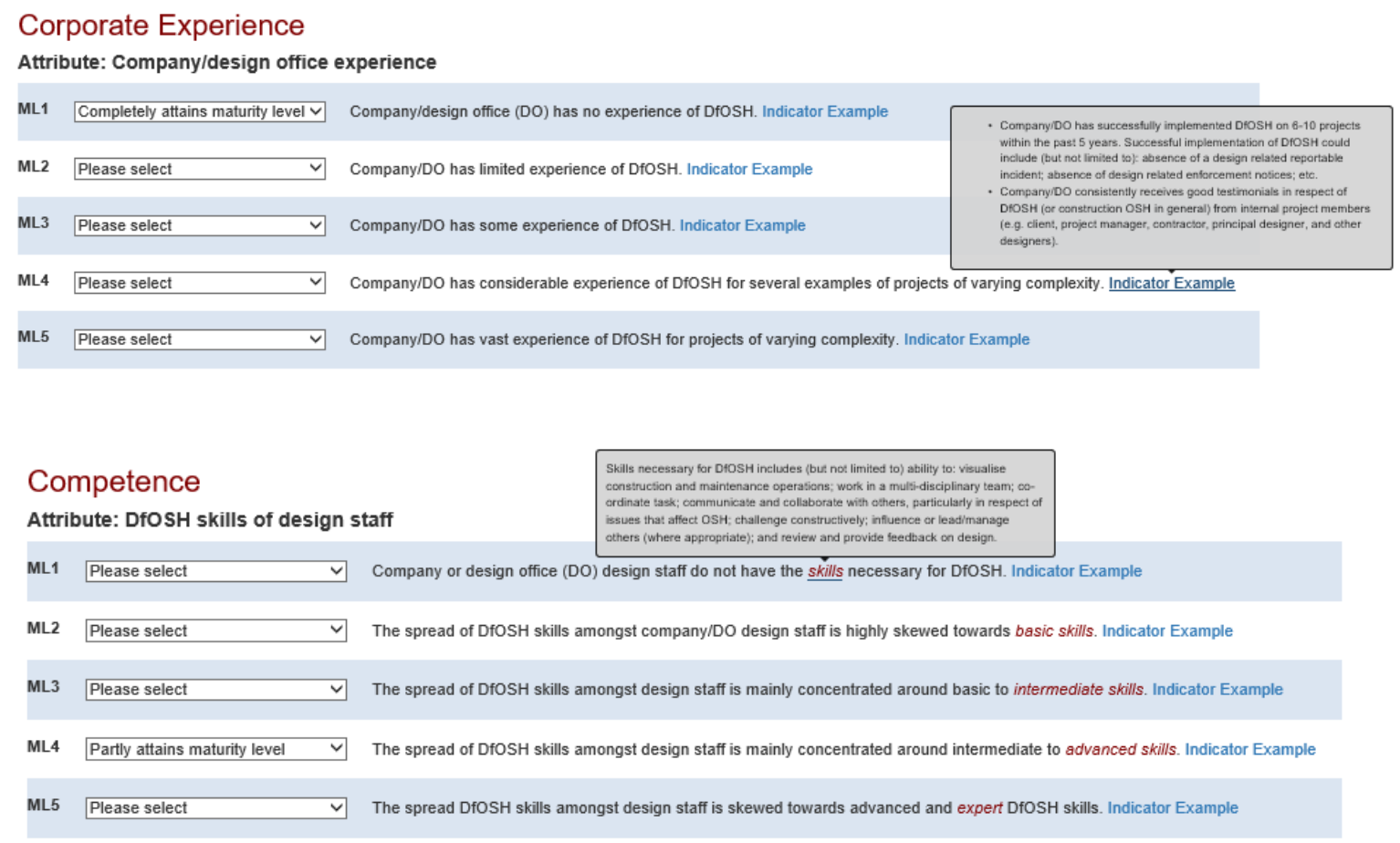

Figure 5: A section of the DfOSH-CMI assessment page

As previously mentioned, these maturity level indicator examples are intended to assist a user in easily undertaking an assessment by offering practical examples of scenarios that depict attainment of a maturity level. In addition to the indicator examples, pop-up display definitions are also provided for some terminologies displayed in red fonts (e.g. "skills" as shown in Figure 5) to enhance user comprehension and ease of use of the tool.

\subsection{Testing of DfOSH-CMI tool}

Maturity models can be evaluated in three main ways (Salah et al., 2014): (1) author evaluation (i.e. evaluation of the model by its authors through assessing the model for its intended use or comparing it with other similar maturity models); (2) domain expert evaluation (i.e. evaluation by experts in the domain of the maturity model and this can be performed through a survey or interviews); and (3) practical setting evaluation (i.e. evaluation through real application of the maturity model). For this study, a combined method of evaluation involving expert evaluation and practical setting evaluation was used in two stages: a pilot evaluation; and a main evaluation. The procedures applied for the pilot and main evaluations are presented below.

\subsubsection{Pilot Evaluation}

The pilot evaluation involved eight experts (see Table 6) who were selected purposively based on the guidance of Hallowell and Gambatese (2010) regarding the criteria for selecting experts (e.g. a professional with knowledge in the subject of inquiry, and a minimum of five years of experience in a role relevant to the research subject). The experts were invited to a research project meeting (lasting about 2 hours) at which the web-based $\mathrm{DfOSH}-\mathrm{CMl}$ tool was demonstrated and its purpose 
explained. Subsequently, the URL to the tool was given to the experts and they were tasked to trial the tool (on computers) at the meeting by using it to undertake a real assessment of either their design organisation or a design organisation/office they knew very well. The experts were asked to take notes of their comments as they progressed with their assessment. Following the meeting, the comments were collated and examined to identify issues with the tool as well as suggestions to improve it. Amongst the comments from the feedback provided are:

- The usefulness of the maturity level indicator examples

- Inconsistencies with the ordering of the capability attributes as displayed by the tool

- Timing out of an assessment and the need to allow users to save an incomplete assessment

- $\quad$ The need for clarity in the texts that describe the purpose of the tool.

- Suggestions to refine some maturity level descriptors as well as indicator examples.

Based on the comments and issues raised by the experts, the DfOSH-CMI tool was modified and then taken forward to the main evaluation.

\subsubsection{Main Evaluation}

40 experts (comprising the professionals who participated in the expert focus group and professionals who joined an industry expert panel assembled for the Delphi expert survey) were invited to test the tool. As previously mentioned, the experts were selected purposively based on the guidance of Hallowell and Gambatese (2010) regarding the criteria for selecting experts (e.g. a professional with knowledge in the subject of inquiry, and a minimum of five years of experience in a role relevant to the research subject). The experts were sent (by email) an evaluation form which was developed based on guidelines for evaluating maturity models (Salah et al., 2014). Salah et al. (2014) indicated that capability maturity models should be evaluated for the following: (a) sufficiency and accuracy of maturity levels; (b) relevance, comprehensiveness, mutual exclusion and accuracy of attributes/key process areas; and (c) ease of understanding, ease of use, usefulness and practicality of the entire maturity model.

The evaluation form used had two main parts: (1) an initial information sheet which was followed by; (2) the main evaluation section. The information sheet included an introductory video step-by-step user guide. The information sheet also included a URL for the DfOSH-CMI tool. On the information sheet, the professionals were asked to view the video first and then proceed to undertake a real organisational capability assessments for a design organisation. Professionals who work in a design organisation/design office were asked to use the tool to assess their own organisation. Those who did not work in a design organisation were asked to base their assessment on a design organisation/design office they were very familiar with in order for the assessment to be realistic. The main evaluation section of the form (see appendix) included evaluation criteria based on Salah et al. (2014) guidelines. The professionals were asked to respond to the criteria after they had used the tool. A five-point Likert agreement scale (i.e., strongly disagree, disagree, neither disagree nor agree, agree, 
strongly agree) was used to obtain responses to the evaluation criteria. Out of the 40 invited experts, 16 participated resulting in a response rate of $40 \%$. The demographic information of the 16 experts is shown in Table 7.

Table 6: Profile of pilot evaluation experts

\begin{tabular}{|c|c|c|c|c|}
\hline $\begin{array}{l}\text { Type of respondent } \\
\text { organisation }\end{array}$ & $\begin{array}{l}\text { Respondent professional } \\
\text { role }\end{array}$ & $\begin{array}{c}\text { Experience in } \\
\text { professional role }\end{array}$ & $\begin{array}{l}\text { Experience in } \\
\text { construction }\end{array}$ & $\begin{array}{c}\text { Professional } \\
\text { affiliation/qualification }\end{array}$ \\
\hline Design consultancy & Architect/principal designer & $\begin{array}{l}31 \text { years as } \\
\text { architect }\end{array}$ & $\begin{array}{l}31 \text { years as } \\
\text { architect }\end{array}$ & RIBA \\
\hline $\begin{array}{l}\text { Infrastructure client } \\
\text { organisation }\end{array}$ & OSH professional & $\begin{array}{l}5 \text { years as OSH } \\
\text { manager, } 7 \\
\text { years as safety } \\
\text { professional, } 20 \\
\text { years as design } \\
\text { manager }\end{array}$ & 17 years & $\mathrm{IOSH}$ \\
\hline Design consultancy & $\begin{array}{l}\text { Principal engineer and safety } \\
\text { advisor }\end{array}$ & $\begin{array}{l}1 \text { year as } \\
\text { principal } \\
\text { engineer, } \\
\text { previously } 6 \\
\text { years as senior } \\
\text { engineer and } 5 \\
\text { years as OSH } \\
\text { advisor }\end{array}$ & 19 years & CEng, ICE \\
\hline Design consultancy & $\begin{array}{l}\text { Civil/structural engineer, } \\
\text { CDM specialist. }\end{array}$ & 28 years & 28 years & ICE, IStructE, APS \\
\hline $\begin{array}{l}\text { Infrastructure client } \\
\text { organisation }\end{array}$ & CDM manager & Over 10 years & Over 20 years & \\
\hline $\mathrm{OSH}$ consultancy & $\begin{array}{l}\text { Civil engineer and OHS } \\
\text { professional }\end{array}$ & 27 years in $\mathrm{OHS}$ & 40 years & ICE, IOSH \\
\hline Contractor organisation & $\begin{array}{l}\text { Health safety quality and } \\
\text { environmental manager }\end{array}$ & 16 years & 24 years & $\mathrm{IOSH}$ \\
\hline Client organisation & Senior quantity surveyor & 20 years & 28 years & RICS \\
\hline \multicolumn{5}{|c|}{$\begin{array}{l}\text { Notes: } \\
\text { APS = Association for Project Safety; CDM = Construction Design and Management Regulations; CEng = Chartered } \\
\text { Engineer; ICE = Institution of Civil Engineers; IOSH = The Institution of Occupational Safety and Health; IStructE = } \\
\text { Institution of Structural Engineers; OSH = Occupational Safety and Health; RIBA = Royal Institute of British Architects; RICS } \\
\text { = Royal Institution of Chartered Surveyors. }\end{array}$} \\
\hline
\end{tabular}

Table 7: Profile of main evaluation experts

\begin{tabular}{|c|c|c|c|c|}
\hline Type of organisation & Professional role & $\begin{array}{l}\text { Experience in } \\
\text { professional role }\end{array}$ & $\begin{array}{l}\text { Experience in } \\
\text { construction }\end{array}$ & $\begin{array}{c}\text { Professional } \\
\text { affiliation/qualification }\end{array}$ \\
\hline OSH consultancy & CDM professional & 23 years & 38 years & $\begin{array}{l}\text { CEng, ICE, IStructE, } \\
\text { CIOB, APS, IOSH }\end{array}$ \\
\hline Design consultancy & $\begin{array}{l}\text { Architect/principal } \\
\text { designer }\end{array}$ & 31 years as architect & $\begin{array}{l}31 \text { years as } \\
\text { architect }\end{array}$ & RIBA \\
\hline Design consultancy & OSH professional & 17 years & 20 years & $\mathrm{IOSH}$ \\
\hline Design consultancy & OSH professional & 17 years & 25 years & $\mathrm{IOSH}$ \\
\hline Real estate organisation & OSH professional & 12 years & 15 years & IOSH, IIRSM, APS \\
\hline Design consultancy & Architect & 15 years & 24 years & RIBA \\
\hline Real estate organisation & OSH consultant & 6.5 years & 10 years & $\mathrm{IOSH}$ \\
\hline $\begin{array}{l}\text { Construction industry } \\
\text { training organisation }\end{array}$ & $\begin{array}{l}\text { Design project } \\
\text { manager }\end{array}$ & $\begin{array}{l}20 \text { years as a } \\
\text { designer/project } \\
\text { manager, } 5 \text { years as } \\
\text { OSH manager }\end{array}$ & 42 years & CEng, ICE, IOSH, APS \\
\hline OSH consultancy & OSH consultant & $\begin{array}{l}10 \text { years as OSH } \\
\text { professional }\end{array}$ & $\begin{array}{l}15 \text { years } \\
\text { (including } \\
\text { facilities } \\
\text { management) }\end{array}$ & IOSH, IIRSM \\
\hline Design consultancy & Architect & 26 years & 29 years & RIBA \\
\hline $\begin{array}{l}\text { Housing client } \\
\text { organisation }\end{array}$ & $\begin{array}{l}\text { Head of contract } \\
\text { services }\end{array}$ & Over 20years & 36 years & CIOB, APS \\
\hline Design consultancy & $\begin{array}{l}\text { Civil/structural } \\
\text { engineer, CDM } \\
\text { specialist. }\end{array}$ & 28 years & 28 years & ICE, IStructE, APS \\
\hline
\end{tabular}




\begin{tabular}{l|l|l|l|l}
$\begin{array}{l}\text { Infrastructure client } \\
\text { organisation }\end{array}$ & $\begin{array}{l}\text { Head of engineering } \\
- \text { infrastructure } \\
\text { projects }\end{array}$ & $\begin{array}{l}3.5 \text { years as head of } \\
\text { engineering and over } 20 \\
\text { years in engineering } \\
\text { design and construction. }\end{array}$ & 27 years & CEng, ICE \\
\hline OSH consultancy & $\begin{array}{l}\text { Civil engineer and } \\
\text { OHS Professional }\end{array}$ & 27 years in OHS & years & ICE, IOSH \\
\hline Contractor organisation & $\begin{array}{l}\text { Health safety quality } \\
\text { and environmental } \\
\text { manager }\end{array}$ & 16 years & 30 years & CIOB \\
\hline Contractor organisation & $\begin{array}{l}\text { Senior design } \\
\text { manager }\end{array}$ & 12 years & \\
\hline $\begin{array}{l}\text { Notes: } \\
\text { APS = Association for Project Safety; CDM = Construction Design and Management Regulations; CEng = Chartered } \\
\text { Engineer; CIOB = Chartered Institute of Building; ICE = Institution of Civil Engineers; IIRSM = International Institute of Risk } \\
\text { and Safety Management; IOSH = The Institution of Occupational Safety and Health; IStructE = Institution of Structural } \\
\text { Engineers; OSH = Occupational Safety and Health; RIBA = Royal Institute of British Architects. }\end{array}$
\end{tabular}

\subsection{Results}

Table 8 shows the 18 DfOSH capability attributes (obtained from the expert FGD) and the underlying notion that informed the formulation of the maturity level descriptors. The table also shows examples of maturity indicators that were suggested by the FGD experts as well as the relevant literature sources that informed the underlying notion of maturity for each attribute. An excerpt of the capability maturity model is also provided in Table 9. For illustrative purposes and for the sake of brevity, Table 9 shows six capability attributes (one from each of the six thematic categories), the five maturity level descriptors for each attributes and the indicator examples for each of the maturity level descriptors. From Table 8 and Table 9 it can be observed how the underlying notion for each of the capability attributes was used to deduce descriptors that show increasing maturation in the capability attributes (displayed in Table 9). For example, for inter-organisational collaboration at Level 1 the design company shows no commitment to the shared OSH vision of projects they are involved in, at level 5 the company continuously develops and sustains long-term collaborative working relationships with other organisations in order to harness and continuously improve collective expertise relevant for DfOSH. Between these two extremes, there is increasing maturation as the company shows limited commitment (at level 2), collaborates reactively (at level 3), and then collaborates proactively (at level 4).

The responses of the 16 experts regarding the assessment criteria are summarised in Table 10. Additionally, five of the practical setting evaluations undertaken by the experts have been selected and presented in Table 11 as case study illustrations. The case study illustrations comprise two large, one medium and two small design organisations. Table 11 provides a summary of the case studies. This includes the DfOSH capability category scores for each of the six thematic categories and the total DfOSH capability maturity score. The feedback of the experts in the main evaluation (Table 10) reveals that for all the evaluation criteria (including sufficiency and accuracy of maturity levels; relevance, comprehensiveness, mutual exclusion and accuracy of attributes; and ease of understanding, ease of use, usefulness and practicality of entire maturity model), at least $80 \%$ of the experts agree or strongly agree that the tool achieves the evaluation criteria. It is noteworthy that in two areas of evaluation (i.e. the relevance of the attributes to DfOSH capability; and whether the maturity level indicator examples make the assessment easy to undertake) $100 \%$ of the experts agree or strongly agree that the tool achieves the evaluation criteria. 
Table 8: DfOSH capability attributes and underlying notion of maturity

\begin{tabular}{|c|c|c|c|}
\hline DfOSH Capability Attributes & $\begin{array}{c}\text { Underlying Notion of Maturity Used in Formulating Maturity } \\
\text { Level Descriptors }\end{array}$ & Example of Attribute Indicators & Literature sources \\
\hline Skills of design staff in relation to DfOSH. & $\begin{array}{l}\text { At higher maturity levels design staff would be able to } \\
\text { successfully demonstrate skills necessary for DfOSH without } \\
\text { supervision and will be able to manage/supervise others. }\end{array}$ & $\begin{array}{l}\text { CVs of design staff and senior } \\
\text { managers. }\end{array}$ & $\begin{array}{l}\text { Association for Project Management } \\
\text { (2004), Macgillivray et al. (2007), Network } \\
\text { Rail (2015) }\end{array}$ \\
\hline Knowledge of design staff in relation to DfOSH. & $\begin{array}{l}\text { As maturity increases, design staff would demonstrate } \\
\text { analysis, synthesis, evaluation and creation of facts, concepts, } \\
\text { patterns, models, etc. related to DfOSH. }\end{array}$ & Design staff qualifications. & $\begin{array}{l}\text { Bloom (1956), Association for Project } \\
\text { Management (2004), Macgillivray et al. } \\
\text { (2007), Network Rail (2015) }\end{array}$ \\
\hline Experience of design staff in relation to DfOSH. & $\begin{array}{l}\text { As maturity increases design staff would have successfully } \\
\text { practised skills necessary for DfOSH on a wide variety of } \\
\text { projects. }\end{array}$ & $\begin{array}{l}\text { CVs of design staff and senior } \\
\text { managers. }\end{array}$ & $\begin{array}{l}\text { Association for Project Management } \\
\text { (2004), Macgillivray et al. (2007), Network } \\
\text { Rail (2015) }\end{array}$ \\
\hline $\begin{array}{l}\text { Access of design staff to competent OSH, } \\
\text { construction/constructability and maintainability } \\
\text { advice. }\end{array}$ & $\begin{array}{l}\text { As maturity increases, there would be ready access to } \\
\text { competent advice and actions taken would be well- } \\
\text { documented/recorded in some form so that they can be re- } \\
\text { used/re-applied when needed. }\end{array}$ & In-house competent personnel. & Health and Safety Executive (2007) \\
\hline $\begin{array}{l}\text { Role definition for design staff and the recruitment } \\
\text { of design staff into roles. }\end{array}$ & $\begin{array}{l}\text { As maturity increases, design staff roles and responsibilities } \\
\text { become clearly defined, recruitment tends to follow a more } \\
\text { structured process and it is more aligned to business } \\
\text { strategy/objectives. }\end{array}$ & Design staff role description. & $\begin{array}{l}\text { Curtis et al. (2001), Office of Road and } \\
\text { Rail and Health and Safety Laboratory } \\
\text { (2017) }\end{array}$ \\
\hline $\begin{array}{l}\text { Design staff continuous professional development } \\
\text { (CPD) in relation to DfOSH. }\end{array}$ & $\begin{array}{l}\text { At higher maturity levels, there will regular provision of DfOSH } \\
\text { related CPD training for design staff. In addition, design staff } \\
\text { would regularly undergo performance and development } \\
\text { review, which informs their CPD training. }\end{array}$ & $\begin{array}{l}\text { CPD training records for design } \\
\text { staff. }\end{array}$ & $\begin{array}{l}\text { Curtis et al. (2001), Health and Safety } \\
\text { Executive (2007), Computer Integrated } \\
\text { Construction Research Program (2013), } \\
\text { Office of Road and Rail and Health and } \\
\text { Safety Laboratory (2017) }\end{array}$ \\
\hline DfOSH policy & $\begin{array}{l}\text { As maturity increases, company DfOSH policy becomes } \\
\text { clearer, well-communicated within the organisation, and } \\
\text { interpreted and applied consistently by all } \\
\text { managers/supervisors and staff. }\end{array}$ & Company policy. & $\begin{array}{l}\text { Computer Integrated Construction } \\
\text { Research Program (2013), Office of Road } \\
\text { and Rail and Health and Safety Laboratory } \\
\text { (2017) }\end{array}$ \\
\hline Top management commitment to DfOSH & $\begin{array}{l}\text { As maturity increases, company senior management } \\
\text { commitment to DfOSH increases. This is mirrored by } \\
\text { provision/allocation of adequate resources to promote DfOSH. }\end{array}$ & $\begin{array}{l}\text { A senior manager acting as } \mathrm{DfOSH} \\
\text { champion within organisation. }\end{array}$ & $\begin{array}{l}\text { Computer Integrated Construction } \\
\text { Research Program (2013), Office of Road } \\
\text { and Rail and Health and Safety Laboratory } \\
\text { (2017) }\end{array}$ \\
\hline $\begin{array}{l}\text { DfOSH research and innovation i.e. organisation's } \\
\text { investment into, conduct of, or exploitation of } \\
\text { existing research to enhance DfOSH, as well as } \\
\text { organisation's ability to be creative in implementing } \\
\text { DfOSH. }\end{array}$ & $\begin{array}{l}\text { Higher maturity levels would be characterised by } \\
\text { institutionalisation of research and development and provision } \\
\text { of an environment for ideas generation and exploitation for } \\
\text { DfOSH. }\end{array}$ & Research and development budget. & $\begin{array}{l}\text { Chiesa (1996), Rogers (2003), Succar } \\
\text { (2009) }\end{array}$ \\
\hline $\begin{array}{l}\text { Corporate experience in implementing DfOSH on } \\
\text { projects. }\end{array}$ & $\begin{array}{l}\text { As maturity increases company would have successfully } \\
\text { implemented DfOSH on several projects of varying complexity } \\
\text { and size. }\end{array}$ & Portfolio of past projects. & $\begin{array}{l}\text { Association for Project Management } \\
\text { (2004), Health and Safety Executive } \\
\text { (2007) }\end{array}$ \\
\hline
\end{tabular}




\begin{tabular}{|c|c|c|c|}
\hline $\begin{array}{l}\text { Organisation's design quality management } \\
\text { systems/processes. }\end{array}$ & $\begin{array}{l}\text { As maturity increases, design quality management becomes } \\
\text { an integral part of design workflow and central to ensuring } \\
\text { conformance of design to proposed DfOSH solutions on } \\
\text { projects. }\end{array}$ & $\begin{array}{l}\text { Certification to ISO } 9001 \text { Quality } \\
\text { Management System. }\end{array}$ & Crosby (1979) \\
\hline $\begin{array}{l}\text { Organisation's design risk management } \\
\text { systems/processes. }\end{array}$ & $\begin{array}{l}\text { As maturity increases, design risk management becomes an } \\
\text { integral part of design function. }\end{array}$ & Design risk register. & $\begin{array}{l}\text { Macgillivray et al. (2007), Office of Road } \\
\text { and Rail and Health and Safety Laboratory } \\
\text { (2017) }\end{array}$ \\
\hline $\begin{array}{l}\text { Organisation's project review systems/processes } \\
\text { for learning DfOSH lessons. }\end{array}$ & $\begin{array}{l}\text { As maturity increases recording of DfOSH related lessons, } \\
\text { sharing and re-use of lessons become institutionalised and } \\
\text { central to DfOSH decision-making. }\end{array}$ & $\begin{array}{l}\text { Participation in post-occupancy } \\
\text { evaluations. }\end{array}$ & $\begin{array}{l}\text { Office of Road and Rail and Health and } \\
\text { Safety Laboratory (2017) }\end{array}$ \\
\hline $\begin{array}{l}\text { Systems/processes for management of } \\
\text { outsourced/subcontracted designers/consultants. }\end{array}$ & $\begin{array}{l}\text { As maturity increases, assessment of competence and } \\
\text { performance of outsourced design services become } \\
\text { formalised, well-structured and such assessment inform future } \\
\text { selection/use of outsourced services. }\end{array}$ & $\begin{array}{l}\text { Company's own prequalification } \\
\text { arrangements. }\end{array}$ & $\begin{array}{l}\text { Health and Safety Executive (2007), Office } \\
\text { of Road and Rail and Health and Safety } \\
\text { Laboratory (2017) }\end{array}$ \\
\hline $\begin{array}{l}\text { Organisation's physical work resources i.e., i.e. } \\
\text { conducive workstation, workspace/workplace } \\
\text { environment, and equipment/materials that support } \\
\text { design and DfOSH. }\end{array}$ & $\begin{array}{l}\text { As maturity increases, physical work resources become } \\
\text { adequate, well-organised and planned for. }\end{array}$ & Workstations and workspace. & $\begin{array}{l}\text { Curtis et al. (2001), Computer Integrated } \\
\text { Construction Research Program (2013) }\end{array}$ \\
\hline $\begin{array}{l}\text { Organisation's ICT resources i.e., computing and } \\
\text { ICT facilities (including hardware and software) } \\
\text { that support DfOSH and communication or sharing } \\
\text { of design information. }\end{array}$ & $\begin{array}{l}\text { Higher maturity levels would be characterised by exploitation } \\
\text { of cutting edge computing and information technology facilities } \\
\text { that support DfOSH. }\end{array}$ & $\begin{array}{l}\text { Advanced visualisation and virtual } \\
\text { prototyping tools. }\end{array}$ & $\begin{array}{l}\text { Curtis et al. (2001), Computer Integrated } \\
\text { Construction Research Program (2013) }\end{array}$ \\
\hline $\begin{array}{l}\text { Intra-organisational collaboration i.e., the ability of } \\
\text { various design units/sections/departments within } \\
\text { organisation to collaborate to implement DfOSH on } \\
\text { projects. }\end{array}$ & $\begin{array}{l}\text { Increase in maturity manifests through familiarity, mutual trust } \\
\text { and free sharing of information between various design } \\
\text { units/sections/departments within the organisation. }\end{array}$ & $\begin{array}{l}\text { Routine company or cross- } \\
\text { departmental meetings. }\end{array}$ & $\begin{array}{l}\text { Fraser et al. (2003), Constructing } \\
\text { Excellence (2004), Maier et al. (2012) }\end{array}$ \\
\hline $\begin{array}{l}\text { Inter-organisational collaboration i.e., the ability of } \\
\text { design firm (as a unit) to collaborate with other } \\
\text { organisations on a project to implement DfOSH. }\end{array}$ & $\begin{array}{l}\text { Higher maturity levels of collaboration are fostered by } \\
\text { developing and maintaining long-term relationship and } \\
\text { strategic relationship planning. Lower maturity levels are } \\
\text { characterised by lack of shared vision. }\end{array}$ & $\begin{array}{l}\text { Participation in routine project } \\
\text { design meetings. }\end{array}$ & $\begin{array}{l}\text { Fraser et al. (2003), Constructing } \\
\text { Excellence (2004), Maier et al. (2008) }\end{array}$ \\
\hline
\end{tabular}


Table 9: An excerpt of DfOSH capability maturity grid

\begin{tabular}{|c|c|c|c|c|c|c|}
\hline \multirow[t]{2}{*}{ Capability Attribute } & \multirow{2}{*}{$\begin{array}{l}\text { Maturity } \\
\text { Level } \\
\text { Information }\end{array}$} & \multicolumn{5}{|c|}{ Maturity Levels } \\
\hline & & Level 1 & Level 2 & Level 3 & Level 4 & Level 5 \\
\hline \multirow[t]{2}{*}{$\begin{array}{l}\text { Corporate } \\
\text { Experience }\end{array}$} & $\begin{array}{l}\text { Maturity } \\
\text { level } \\
\text { descriptors }\end{array}$ & $\begin{array}{l}\text { Company/design office (DO) has no } \\
\text { experience of DfOSH. }\end{array}$ & $\begin{array}{l}\text { Company/DO has limited } \\
\text { experience of DfOSH. }\end{array}$ & $\begin{array}{l}\text { Company/DO has some } \\
\text { experience of DfOSH. }\end{array}$ & $\begin{array}{l}\text { Company/DO has } \\
\text { considerable experience of } \\
\text { DfOSH for several } \\
\text { examples of projects of } \\
\text { varying complexity. }\end{array}$ & $\begin{array}{l}\text { Company/DO has vast } \\
\text { experience of DfOSH for } \\
\text { projects of varying } \\
\text { complexity. }\end{array}$ \\
\hline & $\begin{array}{l}\text { Maturity } \\
\text { level } \\
\text { indicator } \\
\text { examples }\end{array}$ & $\begin{array}{l}\text { - A company/DO with no history of } \\
\text { implementing DfOSH on projects } \\
\text { within the past } 5 \text { years. }\end{array}$ & $\begin{array}{l}\text { - Company/DO has } \\
\text { successfully } \\
\text { implemented DfOSH on } \\
1-2 \text { projects within the } \\
\text { past } 5 \text { years. } \\
\text { Successful } \\
\text { implementation of } \\
\text { DfOSH could include } \\
\text { (but not limited to): } \\
\text { absence of a design } \\
\text { related reportable } \\
\text { incident; absence of } \\
\text { design related } \\
\text { enforcement notices; } \\
\text { etc. }\end{array}$ & $\begin{array}{l}\text { - Company/DO has } \\
\text { successfully } \\
\text { implemented DfOSH on } \\
3-5 \text { projects within the } \\
\text { past } 5 \text { years. Successful } \\
\text { implementation of } \\
\text { DfOSH could include } \\
\text { (but not limited to): } \\
\text { absence of a design } \\
\text { related reportable } \\
\text { incident; absence of } \\
\text { design related } \\
\text { enforcement notices; } \\
\text { etc. }\end{array}$ & $\begin{array}{l}\text { - Company/DO has } \\
\text { successfully } \\
\text { implemented DfOSH on } \\
\text { 6-10 projects within the } \\
\text { past } 5 \text { years. Successful } \\
\text { implementation of } \\
\text { DfOSH could include } \\
\text { (but not limited to): } \\
\text { absence of a design } \\
\text { related reportable } \\
\text { incident; absence of } \\
\text { design related } \\
\text { enforcement notices; etc. } \\
\text { - Company/DO } \\
\text { consistently receives } \\
\text { good testimonials in } \\
\text { respect of DfOSH (or } \\
\text { construction OSH in } \\
\text { general) from internal } \\
\text { project members (e.g. } \\
\text { client, project manager, } \\
\text { contractor, principal } \\
\text { designer, and other } \\
\text { designers). }\end{array}$ & $\begin{array}{l}\text { - Company/DO has } \\
\text { successfully implemented } \\
\text { DfOSH on over } 10 \\
\text { projects within the past } 5 \\
\text { years. } \\
\text { - Company/DO with } \\
\text { extensive track record of } \\
\text { successful } \\
\text { implementation of DfOSH } \\
\text { on large projects. } \\
\text { - Company/DO } \\
\text { consistently receives } \\
\text { good testimonials in } \\
\text { respect of DfOSH (or } \\
\text { construction OSH in } \\
\text { general) from internal } \\
\text { project members (e.g. } \\
\text { client, project manager, } \\
\text { contractor, principal } \\
\text { designer, and other } \\
\text { designers). Additionally, } \\
\text { company/DO consistently } \\
\text { receives } \\
\text { awards/recognitions in } \\
\text { respect of DfOSH from } \\
\text { external industry } \\
\text { bodies/associations e.g. } \\
\text { ICE, RIBA, ClOB, } \\
\text { RoSPA. }\end{array}$ \\
\hline
\end{tabular}




\begin{tabular}{|c|c|c|c|c|c|c|}
\hline \multirow[t]{2}{*}{$\begin{array}{l}\text { DfOSH continuous } \\
\text { professional } \\
\text { development } \\
\text { (CPD) training for } \\
\text { design staff }\end{array}$} & \begin{tabular}{|l|} 
Maturity \\
level \\
descriptors
\end{tabular} & $\begin{array}{l}\text { No provision of DfOSH related CPD } \\
\text { training for design staff. No structured } \\
\text { performance and development review } \\
\text { (PDR) for design staff to ascertain } \\
\text { staff performance and training needs. }\end{array}$ & $\begin{array}{l}\text { Rare provision of DfOSH } \\
\text { related CPD training for } \\
\text { design staff. } \\
\text { Design staff PDR is rarely } \\
\text { undertaken. } \\
\text { DfOSH is rarely } \\
\text { considered in design staff } \\
\text { PDR. }\end{array}$ & $\begin{array}{l}\text { Occasional provision of } \\
\text { DfOSH related CPD } \\
\text { training for design staff. } \\
\text { CPD training is usually } \\
\text { reactive. } \\
\text { Design staff PDR is } \\
\text { sometimes undertaken. } \\
\text { DfOSH is sometimes } \\
\text { considered in design staff } \\
\text { PDR. }\end{array}$ & $\begin{array}{l}\text { Frequent provision of } \\
\text { DfOSH related CPD } \\
\text { training for design staff. } \\
\text { CPD training is usually } \\
\text { proactive. } \\
\text { Design staff regularly } \\
\text { undergo PDR. } \\
\text { DfOSH is always } \\
\text { considered in design staff } \\
\text { PDR. }\end{array}$ & $\begin{array}{l}\text { Design staff DfOSH CPD } \\
\text { training and PDR (which } \\
\text { considers DfOSH) are } \\
\text { integral to the organisation's } \\
\text { human resource } \\
\text { development strategy/plan } \\
\text { and they are embedded } \\
\text { within the organisation's } \\
\text { human resource } \\
\text { development practices. } \\
\text { PDR procedures and } \\
\text { organisational human } \\
\text { resource development } \\
\text { strategy/plan are reviewed } \\
\text { to ensure their up-to-date } \\
\text { suitability and continuous } \\
\text { improvement. }\end{array}$ \\
\hline & $\begin{array}{l}\text { Maturity } \\
\text { level } \\
\text { indicator } \\
\text { examples }\end{array}$ & $\begin{array}{l}\text { - A company/DO that does not } \\
\text { provide or support (e.g. allow time } \\
\text { and funds for) DfOSH or OSH } \\
\text { related CPD training (in-house or } \\
\text { external) for design staff. } \\
\text { - No DfOSH or OSH CPD training } \\
\text { records for design staff within the } \\
\text { past } 12 \text { months. } \\
\text { - No records of PDR for design staff } \\
\text { within the past } 12 \text { months. }\end{array}$ & $\begin{array}{l}\text { - A company/DO that } \\
\text { rarely provides or } \\
\text { supports (e.g. allow } \\
\text { time and funds for) } \\
\text { DfOSH or OSH } \\
\text { related CPD training } \\
\text { (in-house or external) } \\
\text { for design staff. } \\
\text { - Very few DfOSH or } \\
\text { OSH CPD training } \\
\text { records for design } \\
\text { staff within the past } 12 \\
\text { months. } \\
\text { - Few PDR records for } \\
\text { design staff within the } \\
\text { past } 12 \text { months. }\end{array}$ & $\begin{array}{l}\text { - A company/DO that } \\
\text { sometimes provides or } \\
\text { supports (e.g. allow } \\
\text { time and funds for) } \\
\text { DfOSH or OSH related } \\
\text { CPD training (in-house } \\
\text { or external) for design } \\
\text { staff. } \\
\text { - DfOSH or OSH related } \\
\text { CPD training is usually } \\
\text { not informed by design } \\
\text { staff PDR i.e. a } \\
\text { misalignment between } \\
\text { PDR outcomes and } \\
\text { CPD training records } \\
\text { for design staff. } \\
\text { Partial records of } \\
\text { design staff PDR and } \\
\text { CPD training for the } \\
\text { past } 12 \text { months. }\end{array}$ & $\begin{array}{l}\text { - A company/DO that } \\
\text { regularly provides or } \\
\text { supports (e.g. allow } \\
\text { time and funds for) } \\
\text { DfOSH or OSH related } \\
\text { CPD training (in-house } \\
\text { or external) for design } \\
\text { staff. } \\
\text { - DfOSH or OSH related } \\
\text { CPD training is usually } \\
\text { informed by design } \\
\text { staff PDR i.e. there is } \\
\text { usually an alignment } \\
\text { between PDR } \\
\text { outcomes and CPD } \\
\text { training undertaken by } \\
\text { design staff. } \\
\text { Well-kept records of } \\
\text { design staff PDR and } \\
\text { CPD training for the } \\
\text { past } 12 \text { months. }\end{array}$ & $\begin{array}{l}\text { - All design staff } \\
\text { undertake regular } \\
\text { DfOSH related CPD or } \\
\text { OSH training (in-house } \\
\text { or external). } \\
\text { - All design staff regularly } \\
\text { undergo PDR. } \\
\text { - CPD training is always } \\
\text { informed by staff PDR } \\
\text { and wider } \\
\text { organisational human } \\
\text { resource development } \\
\text { strategy/plan i.e. } \\
\text { evidence of alignment } \\
\text { between CPD training } \\
\text { and wider } \\
\text { organisational human } \\
\text { development } \\
\text { strategy/plan. } \\
\text { Examples of review of } \\
\text { PDR procedures and } \\
\text { organisational human } \\
\text { resource development } \\
\text { strategy/plan and the } \\
\text { actions taken. }\end{array}$ \\
\hline $\begin{array}{l}\text { Top management } \\
\text { commitment to } \\
\text { DfOSH }\end{array}$ & \begin{tabular}{|l} 
Maturity \\
level \\
descriptors
\end{tabular} & $\begin{array}{l}\text { No commitment by company/DO } \\
\text { senior management to DfOSH. }\end{array}$ & $\begin{array}{l}\text { Limited commitment by } \\
\text { company/DO senior } \\
\text { management to DfOSH. }\end{array}$ & $\begin{array}{l}\text { Partial commitment by } \\
\text { company/DO senior } \\
\text { management to DfOSH. }\end{array}$ & $\begin{array}{l}\text { Firm commitment by } \\
\text { company/DO senior } \\
\text { management to DfOSH. } \\
\text { Show of commitment is } \\
\text { aligned to company/DO's } \\
\text { policy on DfOSH. }\end{array}$ & $\begin{array}{l}\text { Unwavering and clearly } \\
\text { visible commitment by } \\
\text { company/DO senior } \\
\text { management to DfOSH. }\end{array}$ \\
\hline
\end{tabular}




\begin{tabular}{|c|c|c|c|c|c|c|}
\hline & & & & & & $\begin{array}{l}\text { Show of commitment is } \\
\text { aligned to company/DO } \\
\text { policy on DfOSH. }\end{array}$ \\
\hline & $\begin{array}{l}\text { Maturity } \\
\text { level } \\
\text { indicator } \\
\text { examples }\end{array}$ & $\begin{array}{l}\text { - There is no budget/resource } \\
\text { commitment for DfOSH related } \\
\text { issues e.g. training of design staff. } \\
\text { - DfOSH or construction OSH in } \\
\text { general is not discussed at } \\
\text { company/DO board/senior } \\
\text { management meetings (e.g. } \\
\text { shown by minutes of meeting). } \\
\text { - DfOSH or construction OSH in } \\
\text { general does not feature in } \\
\text { company/DO annual reports. }\end{array}$ & 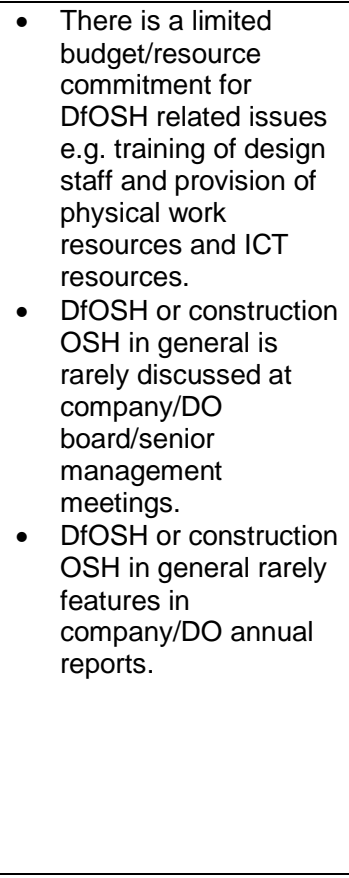 & $\begin{array}{l}\text { - There is some } \\
\text { resource provision for } \\
\text { DfOSH related issues } \\
\text { e.g. training of design } \\
\text { staff and provision of } \\
\text { physical work } \\
\text { resources and ICT } \\
\text { resources. } \\
\text { - Show of commitment } \\
\text { is usually reactive e.g. } \\
\text { when significant risks } \\
\text { are anticipated or in } \\
\text { response to a major } \\
\text { OSH incident. } \\
\text { DfOSH or construction } \\
\text { OSH in general is } \\
\text { occasionally } \\
\text { discussed at } \\
\text { company/DO } \\
\text { board/senior } \\
\text { management } \\
\text { meetings. } \\
\text { DfOSH or construction } \\
\text { OSH in general } \\
\text { occasionally features } \\
\text { in company/DO } \\
\text { annual reports. }\end{array}$ & $\begin{array}{l}\text { - There is adequate } \\
\text { resource provision for } \\
\text { DfOSH related issues } \\
\text { e.g. training of design } \\
\text { staff and provision of } \\
\text { physical work } \\
\text { resources and ICT } \\
\text { resources. } \\
\text { - Senior managers are } \\
\text { amongst the DfOSH } \\
\text { champions within the } \\
\text { company/DO. } \\
\text { - DfOSH or construction } \\
\text { OSH in general is often } \\
\text { discussed at } \\
\text { company/DO } \\
\text { board/senior } \\
\text { management meetings. } \\
\text { DfOSH or construction } \\
\text { OSH in general often } \\
\text { features in } \\
\text { company/DO annual } \\
\text { reports. }\end{array}$ & $\begin{array}{l}\text { - There is an adequate } \\
\text { and a ring-fenced } \\
\text { resource commitment } \\
\text { for DfOSH related } \\
\text { issues. } \\
\text { - Company/DO senior } \\
\text { managers are amongst } \\
\text { DfOSH champions } \\
\text { within the industry and } \\
\text { are recognised as } \\
\text { industry thought- } \\
\text { leaders in relation to } \\
\text { DfOSH and } \\
\text { construction OSH in } \\
\text { general. } \\
\text { Company/DO senior } \\
\text { manager(s) are/have } \\
\text { been involved in high- } \\
\text { level industry } \\
\text { DfOSH/OSH } \\
\text { committees/task } \\
\text { groups, authoring of } \\
\text { industry DfOSH/OSH } \\
\text { outputs such as report, } \\
\text { standard, guidelines } \\
\text { and handbook. }\end{array}$ \\
\hline $\begin{array}{l}\text { Design quality } \\
\text { management } \\
\text { systems }\end{array}$ & $\begin{array}{l}\text { Maturity } \\
\text { level } \\
\text { descriptors }\end{array}$ & $\begin{array}{l}\text { No processes/procedures for design } \\
\text { quality management. }\end{array}$ & $\begin{array}{l}\text { Rare use of design quality } \\
\text { management } \\
\text { processes/procedures } \\
\text { within company/DO. } \\
\text { Design quality standards } \\
\text { are poorly defined. }\end{array}$ & $\begin{array}{l}\text { Occasional and reactive } \\
\text { use of design quality } \\
\text { management } \\
\text { processes/procedures } \\
\text { within company/DO. } \\
\text { Design quality } \\
\text { management } \\
\text { processes/procedures } \\
\text { may reference some } \\
\text { aspects of best practice } \\
\text { quality management } \\
\text { standards e.g. ISO } 9001 \\
\text { Quality Management } \\
\text { System. Design quality }\end{array}$ & $\begin{array}{l}\text { Consistent application of } \\
\text { design quality management } \\
\text { processes/procedures } \\
\text { within company/DO. } \\
\text { Design quality } \\
\text { management } \\
\text { processes/procedures are } \\
\text { an integral part of design } \\
\text { workflow within } \\
\text { organisation. Design error } \\
\text { and rework prevention is a } \\
\text { routine part of company/DO } \\
\text { design operation. Design } \\
\text { quality management } \\
\text { processes/procedures are }\end{array}$ & $\begin{array}{l}\text { Design quality management } \\
\text { processes/procedures, } \\
\text { including the concept of } \\
\text { "right the first time", are } \\
\text { institutionalised within the } \\
\text { company/DO and are } \\
\text { considered as a measure of } \\
\text { operational excellence. The } \\
\text { company/DO is seen as an } \\
\text { industry thought leader in } \\
\text { quality management. } \\
\text { Processes/procedures are } \\
\text { routinely reviewed to ensure } \\
\text { continuous improvement } \\
\text { that is in line with industry }\end{array}$ \\
\hline
\end{tabular}




\begin{tabular}{|c|c|c|c|c|c|c|}
\hline & & & & $\begin{array}{l}\text { standards are well- } \\
\text { defined. }\end{array}$ & $\begin{array}{l}\text { modelled on best practice } \\
\text { quality management } \\
\text { standards e.g. ISO } 9001 \\
\text { Quality Management } \\
\text { System. }\end{array}$ & $\begin{array}{l}\text { best-performing } \\
\text { organisations. }\end{array}$ \\
\hline & $\begin{array}{l}\text { Maturity } \\
\text { level } \\
\text { indicator } \\
\text { examples }\end{array}$ & $\begin{array}{ll} & \text { A company/DO that does not } \\
\text { have processes/procedures for } \\
\text { managing design quality. } \\
\text { - } \quad \text { Frequent errors in design. } \\
\text { - High volume of rework. }\end{array}$ & $\begin{array}{ll}- & \text { Design quality } \\
\text { management } \\
\text { processes/procedures } \\
\text { not well-structured. } \\
\text { - } \quad \text { Frequent errors in } \\
\text { design. } \\
\text { - } \quad \text { High volume of } \\
\text { rework. } \\
\text { - Vague/unclear quality } \\
\text { standards. }\end{array}$ & 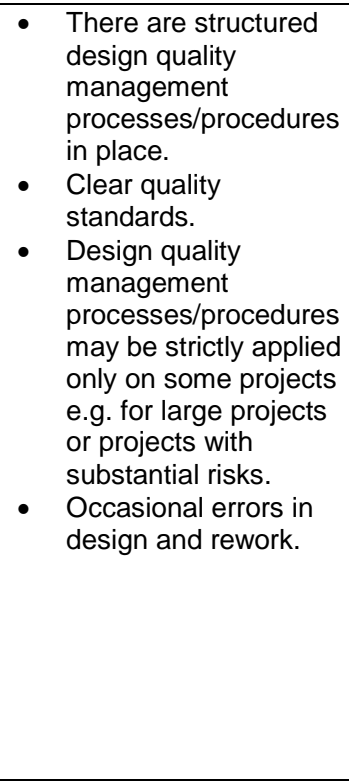 & 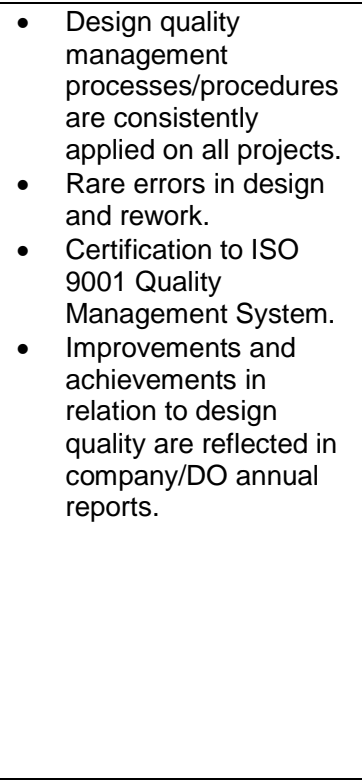 & 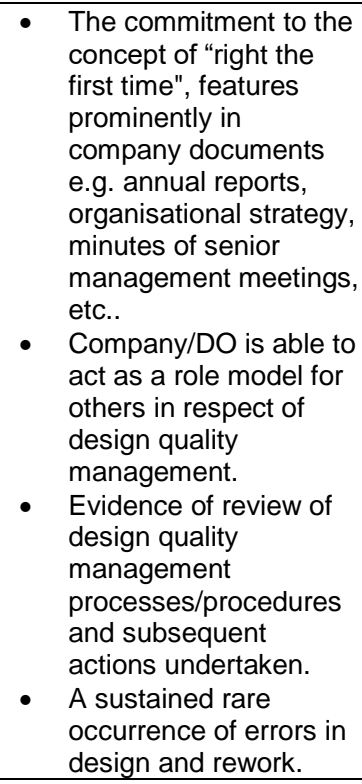 \\
\hline ICT resources & $\begin{array}{l}\text { Maturity } \\
\text { level } \\
\text { Indicator } \\
\text { examples }\end{array}$ & $\begin{array}{l}\text { No or very little ICT resources } \\
\text { (including software and hardware) to } \\
\text { support DfOSH. }\end{array}$ & $\begin{array}{l}\text { ICT resources that } \\
\text { support design function } \\
\text { (including DfOSH) are } \\
\text { available but not } \\
\text { standardised across } \\
\text { company/DO. } \\
\text { Specifications of ICT } \\
\text { resources are basic and } \\
\text { not consistent. }\end{array}$ & $\begin{array}{l}\text { ICT resources that support } \\
\text { design function (including } \\
\text { DfOSH) are available and } \\
\text { standardised across } \\
\text { company/DO. } \\
\text { Specifications of ICT } \\
\text { resources are just } \\
\text { adequate and } \\
\text { standardised. }\end{array}$ & $\begin{array}{l}\text { ICT resources that support } \\
\text { design function (including } \\
\text { DfOSH) are widely } \\
\text { available, standardised and } \\
\text { managed according to a } \\
\text { resource plan. } \\
\text { Specifications of ICT } \\
\text { resources are advanced } \\
\text { and of a high standard. }\end{array}$ & $\begin{array}{l}\text { Cutting-edge ICT resources } \\
\text { that support design function } \\
\text { (including DfOSH) are } \\
\text { available, standardised and } \\
\text { considered as a core } \\
\text { measure of operational } \\
\text { excellence. } \\
\text { Specifications of ICT } \\
\text { resources are the most up } \\
\text { to date and of the highest } \\
\text { standards. } \\
\text { ICT resources are regularly } \\
\text { reviewed for their up-to-date } \\
\text { suitability to ensure } \\
\text { continuous improvement in } \\
\text { the use of digital } \\
\text { technologies for design } \\
\text { function (including DfOSH). }\end{array}$ \\
\hline
\end{tabular}




\begin{tabular}{|c|c|c|c|c|c|c|}
\hline & $\begin{array}{l}\text { Maturity } \\
\text { level } \\
\text { descriptors }\end{array}$ & $\begin{array}{l}\text { - A company/DO that is } \\
\text { characterised by a high reliance } \\
\text { on manual/paper based tools for } \\
\text { DfOSH. }\end{array}$ & $\begin{array}{l}\text { Digital technologies } \\
\text { that support design } \\
\text { function (including } \\
\text { DfOSH) are used on } \\
\text { few projects. } \\
\text { Examples of such } \\
\text { technologies include: } \\
\text { 2D CAD and printing, }\end{array}$ & $\begin{array}{l}\text { - Digital technologies } \\
\text { that support design } \\
\text { function (including } \\
\text { DfOSH) are used on } \\
\text { projects. Examples of } \\
\text { such technologies } \\
\text { include: 2D CAD and } \\
\text { printing. } \\
\text { - Occasional use of } \\
\text { some advanced digital } \\
\text { tools e.g. 3D BIM. } \\
\text { Company/DO has a } \\
\text { resource plan, but it is } \\
\text { occasionally followed } \\
\text { (e.g. in cases of an } \\
\text { emergency) i.e. some } \\
\text { misalignment between } \\
\text { planned and provided } \\
\text { ICT resources. }\end{array}$ & $\begin{array}{l}\text { - Advanced digital tools } \\
\text { that support DfOSH } \\
\text { are commonly used on } \\
\text { projects. Examples of } \\
\text { such technologies } \\
\text { include: 3D BIM, } \\
\text { virtual and mixed } \\
\text { reality, cloud } \\
\text { computing, big data } \\
\text { technologies, GIS, 3D } \\
\text { printing, drone } \\
\text { technologies, image } \\
\text { mapping and thermal } \\
\text { imaging technologies. } \\
\text { Company/DO has a } \\
\text { resource plan which } \\
\text { informs timely } \\
\text { allocation/provision of } \\
\text { ICT resources i.e. a } \\
\text { good alignment } \\
\text { between planned and } \\
\text { provided ICT } \\
\text { resources. }\end{array}$ & $\begin{array}{l}\text { - Company/DO is often a } \\
\text { trail-blazer in digital } \\
\text { technology use for } \\
\text { design function } \\
\text { (including DfOSH). } \\
\text { - Examples of } \\
\text { company/DO resource } \\
\text { plans over a period of } \\
\text { time and the resulting } \\
\text { resources that were } \\
\text { provided. }\end{array}$ \\
\hline \multirow[t]{2}{*}{$\begin{array}{l}\text { Inter- } \\
\text { organisational } \\
\text { collaboration }\end{array}$} & $\begin{array}{l}\text { Maturity } \\
\text { level } \\
\text { indicator } \\
\text { examples }\end{array}$ & $\begin{array}{l}\text { Company/ design office (DO) shows } \\
\text { no commitment to the shared OSH } \\
\text { vision of projects they are involved in. }\end{array}$ & $\begin{array}{l}\text { Company/DO shows } \\
\text { limited commitment to the } \\
\text { shared OSH vision of } \\
\text { projects they are involved } \\
\text { in. }\end{array}$ & $\begin{array}{l}\text { Collaboration by } \\
\text { company/DO with other } \\
\text { project team members is } \\
\text { usually only reactive. }\end{array}$ & $\begin{array}{l}\text { Collaboration by } \\
\text { company/DO with other } \\
\text { project team members is } \\
\text { usually proactive in order to } \\
\text { ensure effective delivery of } \\
\text { OSH and other project } \\
\text { objectives. }\end{array}$ & $\begin{array}{l}\text { Company/DO continuously } \\
\text { develops and sustains long- } \\
\text { term collaborative working } \\
\text { relationships with other } \\
\text { organisations in order to } \\
\text { harness and continuously } \\
\text { improve collective expertise } \\
\text { relevant for DfOSH or } \\
\text { construction OSH in } \\
\text { general. }\end{array}$ \\
\hline & $\begin{array}{l}\text { Maturity } \\
\text { level } \\
\text { descriptors }\end{array}$ & $\begin{array}{l}\text { A company/DO that solely looks } \\
\text { after its interests and design tasks } \\
\text { on projects. } \\
\text { - A company that has no } \\
\text { history/record/evidence/testimonial } \\
\text { of showing initiatives on projects in } \\
\text { respect of DfOSH/OSH to ensure } \\
\text { successful project outcomes. }\end{array}$ & $\begin{array}{l}\text { - A company/DO that } \\
\text { shows limited concern } \\
\text { for the interests, } \\
\text { design tasks/tasks of } \\
\text { other project team } \\
\text { members. } \\
\text { - Limited participation in } \\
\text { routine design/project } \\
\text { meetings. }\end{array}$ & $\begin{array}{l}\text { A company/DO that } \\
\text { usually collaborates } \\
\text { with other project team } \\
\text { members only if } \\
\text { requested in order to } \\
\text { fulfil their own } \\
\text { responsibilities } \\
\text { (including OSH } \\
\text { responsibilities) and } \\
\text { also for other project } \\
\text { team members to fulfil } \\
\text { their responsibilities. } \\
\text { - A company/DO that is } \\
\text { usually protective of } \\
\text { relevant OSH }\end{array}$ & $\begin{array}{l}\text { A company/DO that } \\
\text { freely shares relevant } \\
\text { OSH information with } \\
\text { other project team } \\
\text { members in a timely } \\
\text { manner. } \\
\text { - A company/DO that } \\
\text { proactively seeks and } \\
\text { obtains adequate pre- } \\
\text { construction/site } \\
\text { information to inform } \\
\text { design. Evidence of } \\
\text { obtaining pre- } \\
\text { construction/site } \\
\text { information could }\end{array}$ & $\begin{array}{l}\text { Company's involvement } \\
\text { in strategic partnering } \\
\text { or project-specific } \\
\text { partnering relationships } \\
\text { that is both committed } \\
\text { to and actually delivers } \\
\text { positive DfOSH } \\
\text { outcomes or } \\
\text { construction OSH } \\
\text { outcomes in general. }\end{array}$ \\
\hline
\end{tabular}




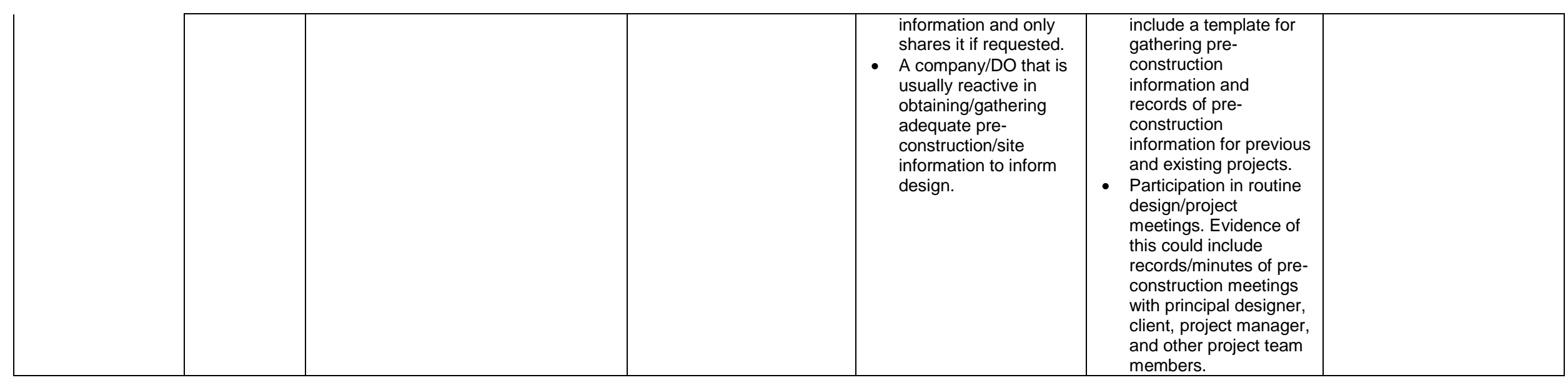


Table 10: Expert evaluation feedback

\begin{tabular}{|c|c|c|c|c|c|c|c|c|}
\hline \multirow[t]{2}{*}{ Assessment criteria } & \multirow[t]{2}{*}{ Mean } & \multirow[t]{2}{*}{$\begin{array}{l}\text { Standard } \\
\text { deviation }\end{array}$} & \multirow[t]{2}{*}{ Median } & \multirow[t]{2}{*}{ Mode } & \multirow[t]{2}{*}{$\begin{array}{l}\% \text { of Agree } \\
\text { or strongly } \\
\text { agree }\end{array}$} & \multirow[t]{2}{*}{$r_{W G}{ }^{a}$} & \multicolumn{2}{|c|}{$\begin{array}{c}\text { Overall assessment of level of } \\
\text { agreement (based of approximation of } \\
\text { mean to scale point) }\end{array}$} \\
\hline & & & & & & & Strongly agree & Agree \\
\hline \multicolumn{9}{|l|}{ Attributes } \\
\hline Attributes are relevant to $\mathrm{DfOSH}$ capability. & 4.63 & 0.50 & 5 & 5 & $100 \%$ & 0.875 & \multirow[t]{4}{*}{$\checkmark$} & \\
\hline Attributes cover all aspects of DfOSH capability. & 4.44 & 0.63 & 4.5 & 5 & $94 \%$ & 0.802 & & $\checkmark$ \\
\hline $\begin{array}{l}\text { Attributes are correctly assigned to their respective maturity } \\
\text { level. }\end{array}$ & 4.19 & 0.98 & 4.5 & 5 & $75 \%$ & 0.519 & & $\checkmark$ \\
\hline Attributes are clearly distinct. & 4.44 & 0.81 & 5 & 5 & $94 \%$ & 0.669 & & $\checkmark$ \\
\hline $\begin{array}{l}\text { Maturity levels } \\
\text { The maturity levels sufficiently represent maturation in the } \\
\text { attributes. }\end{array}$ & 4.06 & 0.85 & 4 & 4 & $81 \%$ & 0.635 & & $\checkmark$ \\
\hline $\begin{array}{l}\text { There is no overlap detected between descriptions of maturity } \\
\text { levels. }\end{array}$ & 4.38 & 0.62 & 4 & 4 & $94 \%$ & 0.808 & & $\checkmark$ \\
\hline $\begin{array}{l}\text { Ease of understanding } \\
\text { The maturity levels are understandable }\end{array}$ & 4.19 & 0.91 & 4 & 5 & $81 \%$ & 0.585 & \multirow{4}{*}{$\checkmark$} & $\checkmark$ \\
\hline The indicator examples are understandable & 4.50 & 0.63 & 5 & 5 & $94 \%$ & 0.800 & & \\
\hline The results are understandable & 4.25 & 0.68 & 4 & 4 & $88 \%$ & 0.767 & & $\checkmark$ \\
\hline $\begin{array}{l}\text { The documentation (i.e. information on the webpages e.g. } \\
\text { home page, etc.) is understandable }\end{array}$ & 4.25 & 0.58 & 4 & 4 & $94 \%$ & 0.833 & & $\checkmark$ \\
\hline \multicolumn{9}{|l|}{ Ease of use } \\
\hline $\begin{array}{l}\text { The scoring scheme (i.e. drop-down options for maturity } \\
\text { levels) is easy to use }\end{array}$ & 4.44 & 0.81 & 5 & 5 & $94 \%$ & 0.669 & \multirow{4}{*}{$\checkmark$} & $\checkmark$ \\
\hline $\begin{array}{l}\text { The indicator examples make the assessment easy to } \\
\text { undertake }\end{array}$ & 4.69 & 0.48 & 5 & 5 & $100 \%$ & 0.885 & & \\
\hline The online navigation of DfOSH-CMI is easy & 4.44 & 0.73 & 5 & 5 & $88 \%$ & 0.735 & & $\checkmark$ \\
\hline $\begin{array}{l}\text { The introductory video helped me to understand how to use } \\
\text { the tool }\end{array}$ & 4.25 & 0.86 & 4 & 4 & $88 \%$ & 0.633 & & $\checkmark$ \\
\hline \multicolumn{9}{|l|}{ Usefulness and practicality } \\
\hline $\mathrm{DfOSH}-\mathrm{CMI}$ is useful for assessing DfOSH capability & 4.13 & 0.81 & 4 & 4 & $88 \%$ & 0.675 & & $\checkmark$ \\
\hline DfOSH-CMI is practical for use in industry & 3.88 & 0.89 & 4 & 4 & $81 \%$ & 0.608 & & $\checkmark$ \\
\hline
\end{tabular}

options (i.e., $1=$ strongly disagree, $2=$ disagree, $3=$ neither disagree nor Agree, $4=$ agree, $5=$ strongly agree). 
Table 11: Summary of DfOSH capability assessment for case studies

\begin{tabular}{|c|c|c|c|c|c|c|c|c|c|c|}
\hline \multirow{2}{*}{$\begin{array}{l}\text { Organisation } \\
\text { ID }\end{array}$} & \multirow{2}{*}{$\begin{array}{l}\text { a Company } \\
\text { size }\end{array}$} & \multirow[t]{2}{*}{ Sector } & \multicolumn{6}{|c|}{ DfOSH capability category maturity score } & \multirow{2}{*}{$\begin{array}{c}\text { Total } \\
\text { DfOSH } \\
\text { capability } \\
\text { maturity } \\
\text { score }\end{array}$} & \multirow{2}{*}{ 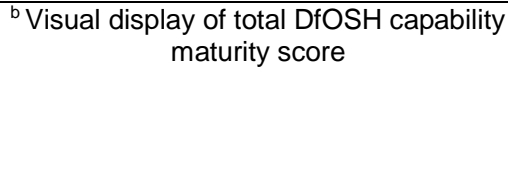 } \\
\hline & & & $\begin{array}{l}\text { Corporate } \\
\text { Experience }\end{array}$ & Competence & Collaboration & Infrastructure & Strategy & Systems & & \\
\hline 1 & Small & Civil engineering & 2.50 & 2.92 & 2.99 & 2.50 & 3.14 & 2.38 & 2.82 & \\
\hline 2 & Small & Building & 3.50 & 3.35 & 3.50 & 3.77 & 3.14 & 3.83 & 3.46 & \\
\hline 3 & Large & $\begin{array}{l}\text { Building, civil } \\
\text { engineering, } \\
\text { electrical } \\
\text { engineering, } \\
\text { mechanical } \\
\text { engineering, and } \\
\text { process engineering }\end{array}$ & 4.00 & 3.89 & 4.50 & 3.24 & 3.62 & 3.73 & 3.89 & \\
\hline 4 & Medium & Building & 5.00 & 4.36 & 4.49 & 3.83 & 5.00 & 4.88 & 4.65 & \\
\hline
\end{tabular}




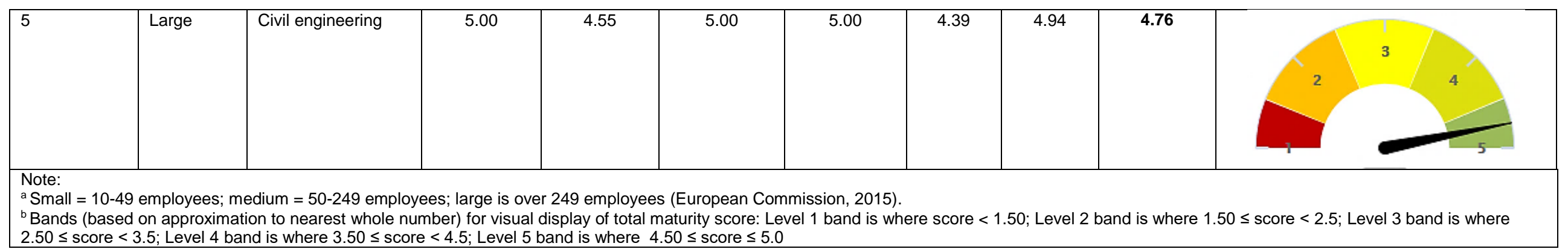


The rwg values (used to measure agreement amongst a group of raters (James et al., 1984)) indicate significant consensus amongst the experts since the rwG values are greater than the $95 \%$ confidence interval cut-off value of 0.369 . This implies that the aggregated (i.e. mean) agreement ratings can be considered as being credible representations of the experts' judgement regarding the evaluation of the tool. The mean ratings range from 4.69 to 3.88 . Approximation of the mean ratings (by rounding to the nearest point on the five-point scale to ensure conformity with the scale) so as to aid interpretation reveals that the experts generally strongly agree or agree that the tool achieves the evaluation criteria. Altogether these results indicate that the $\mathrm{DfOSH}$ $\mathrm{CMI}$ tool adequately meets the evaluation criteria for capability maturity model development.

\subsection{Discussion}

The emergent DfOSH capability attributes have resemblance to some of the key process areas/criteria used in existing capability maturity grids. For example, Strutt et al.'s (2006) design safety capability maturity model for the offshore sector proposed attributes such as education and training, research and development, organisational learning, and managing of safety in the supply chain. The safety culture maturity model by HSE (2000) also contained attributes including 'training', 'management commitment and visibility', 'learning organisation', and 'safety resources'. Outside the area of safety, Succar (2009) proposed a building information modelling maturity matrix comprising capability attributes labelled as 'BIM competency sets'. These attributes included leadership, human resources (encompassing competencies, roles and experience), physical infrastructure, hardware and software. From Table 8 , it is evident that the DfOSH capability attributes (e.g. DfOSH CPD training, DfOSH research and innovation, organisation's project review systems/processes for learning $\mathrm{DfOSH}$ lessons, systems/processes for management of outsourced/subcontracted designers/consultants, top management commitment to DfOSH, ICT resources and physical resources) share similarities with the above mentioned attributes in the models by HSE (2000), Strutt et al.'s (2006) and Succar (2009), although the attributes in Table 8 have specific relevance or focus on the implementation of DfOSH by construction organisations with design responsibilities. In broad terms, the DfOSH capability attributes also reflect the categories/classification of attributes used in existing capability maturity grids such as 'technology', 'process' and 'policy' (Succar, 2009).

Regarding the expert evaluation, it is noteworthy that the $\mathrm{DfOSH}-\mathrm{CMI}$ tool on the whole meets all the assessment criteria. The results of the expert evaluation thus supports the robustness of the tool as a means for assessing the DfOSH capability of design organisations. It is also notable that all the experts at least agree that the maturity level indicators examples make the assessment easy to undertake. Several of the extant capability maturity models (see Table 2, Maier et al., 2012; Filho and Waterson, 2018) commonly only provide maturity level descriptors which users are expected to rely on to undertake capability assessments. While these descriptors are supposed to aid assessments, their utility in that regard can be limited as they can be unclear in terms of conveying the possible situations/conditions that depict attainment of a particular 
maturity level. As shown by the expert evaluation results, providing maturity level indicator examples (i.e., practical scenario depictions of attainment of maturity levels) to supplement or contextualise maturity level descriptors is useful.

Table 11 shows that the DfOSH-CMI tool is able to compute the DfOSH capability maturity score of design organisations from an array of 18 weighted capability attributes. The capability maturity score is two-pronged: (1) at the level of thematic category of attributes; and (2) the overall/total capability maturity score (accompanied by a visual banded display of capability maturity score). Table 11 thus demonstrates that the DfOSH organisational capability score of design organisations could vary for organisations of the same as well as different size and sector of operation. Therefore simplistic "pass" or "fail" verdicts offered by some existing industry safety assessment schemes (e.g. the application of the British Standards Institution (2013) Publicly Available Specification (PAS) 91:2013 by safety schemes in procurement in UK) is far less insightful and provides very limited opportunity for assessed organisations to understand in greater depth the areas of their capability strengths and weaknesses. On the other hand, the assessment scores provided by the DfOSH-CMI tool could enable a design organisation and other stakeholders undertaking a capability assessment to understand with greater depth of clarity the aspects of an organisation's capability that are strong and deficient. For a design organisation such an insight could inform subsequent capability development efforts. For example, considering the DfOSH capability assessments for organisation 4 and organisation 5 , it is evident that while both organisations have a similar overall DfOSH capability maturity (i.e. maturity level band 5), organisation 5 is stronger in terms of the infrastructure category and competence category. Conversely, organisation 4 is stronger in terms of the strategy category. This depth of capability assessment shows the specific areas where each of the organisations would possibly need to invest in order to further enhance the organisation's capability. Assuming that these two organisations are design offices of one parent design company, such assessments could also be viewed from the perspective of an organisational internal benchmarking exercise and potentially inform strategic investment decision regarding DfOSH capability development across the offices of the parent company.

Overall, by considering the capability maturity concept, as employed in several topics in construction and in other disciplines and applying it to DfOSH capability, the study has developed a tool that would be beneficial to several construction sector stakeholders. The implications of DfOSH-CMI tool are expounded in the following section.

\subsection{Conclusions}

$\mathrm{DfOSH}$ is increasingly gaining ground in the global construction sector. It entails firms in design roles producing designs that are safer for workers to build and maintain. Such firms therefore need to have the appropriate level of capability in terms of $\mathrm{DfOSH}$. Design firms would have varying DfOSH capability and it is important that they understand their capability so that they are able to improve. Likewise it is beneficial that construction clients, their representatives or entities engaging the services of design organisations are also able to ascertain the DfOSH capability of those organisations. This study has addressed an important research gap regarding how 
DfOSH capability can be assessed or ascertained. In doing so, the research has shown that the CMM concept can be applied to the domain of DfOSH to develop a DfOSH CMM for assessing the capability of design organisations to implement $\mathrm{DfOSH}$. In this regard, the research has offered an array of capability maturity descriptors that depict stages of maturation in capability attributes for DfOSH. Additionally, the research has offered an approach (including an algorithm) that can be used for computing capability maturity score for DfOSH. Overall, this study has therefore addressed an important research gap by pioneering the development of a web-based DfOSH capability maturity model (called DfOSH-CMI) for the construction industry. The model shows five distinct levels of maturation in distinct DfOSH capability attributes. To ensure its relevance and practical utility, the model has undergone two stages of testing involving expert evaluation and evaluation using practical settings (i.e. design organisations). The testing results have shown the soundness of the tool and it is therefore anticipated that it would be beneficial to industry stakeholders including clients, client representatives, design organisations and design and build contractors.

\subsection{Implications}

The main implications of the research are three-fold: DfOSH capability development/improvement; pre-qualification; and maturity model development. These are elaborated as follows.

\subsubsection{DfOSH capability development/improvement}

- Design organisations (e.g. architectural and engineering design firms) within the built environment could use DfOSH-CMl to self-assess their DfOSH capability and on that basis make informed plans and take action to improve their capability. Like design firms, design and build contractors (particularly those with in-house design units) could also use the DfOSH-CMI tool for selfassessment in order to inform their strategy to continuously improve their DfOSH capability. Using DfOSH-CMI for self-assessment would be beneficial, especially, to small-medium size organisations who normally constitute the bulk of organisations within the construction sector of countries but are often constrained in terms of the resources needed to improve their capacity (see Kheni et al. (2008), ONS (2011), Manu et al. (2018), and Simukonda et al. (2018)).

- Aligned to self-assessment, as previously alluded, DfOSH-CMI could be used by large design organisations with multiple design offices in different locations (e.g. across a country or multiple countries) to benchmark the DfOSH capability of their design offices. Such benchmarking exercises could highlight the areas of strength and deficiency in the DfOSH capability across the company's design offices and consequently enable prioritisation of capability improvement actions e.g. actions targeted at offices with lower capability. Additionally, internal benchmarking of DfOSH capability could facilitate understanding of differences in the implementation of DfOSH amongst the design offices of a large design organisation.

\subsubsection{Pre-qualification}

- Clients or client representatives, when appointing design firms, could use $\mathrm{DfOSH}-\mathrm{CMI}$ as part of their prequalification arrangements to ascertain the DfOSH capability of such firms to ensure that firms being appointed have the 
needed DfOSH capability. In UK and other countries such as Singapore and some European countries where the European Directive 92/57/EEC has been adapted, there are legislative requirements regarding ascertaining the competence and suitability of designers in respect of DfOSH (e.g. the UK CDM regulations, the Workplace Safety and Health (Design for Safety) Regulations 2015 of Singapore, and the Safety, Health and Welfare at Work (Construction) Regulations 2013 of Ireland). In such countries DfOSH-CMI could assist clients or their representatives (e.g. project managers and OSH advisors) to fulfil their legal duties. Even in countries without similar regulatory requirements, it would be useful for clients to ascertain the DfOSH capability of design organisations as part of designer selection as their capability would affect the organisations' ability to effectively mitigate $\mathrm{OSH}$ hazards through design decisions.

\subsubsection{Implications for research/maturity model development}

- Maturity model development usually does not go beyond the formulation of maturity level descriptors to provide examples of practical scenarios or evidence to match those descriptors (Maier et al., 2012). The maturity level indicator examples (i.e. scenario depictions of attainment of a maturity level) incorporated in the development of the DfOSH-CMI tool to complement maturity level descriptors can thus be seen as a contribution to the field of maturity model development. The evaluation results (Table 10) showed that the maturity level indicator examples incorporated into the $\mathrm{DfOSH}-\mathrm{CMI}$ tool made assessment easy for the experts. The results show that the incorporation of maturity level indicator examples to complement maturity level descriptors in the development of maturity models can be a useful means of easing end-user experience in applying such models. Incorporation of maturity level indicator examples could consequently augment the use of maturity models for continuous process improvement in various industrial sectors. In view of this, developers of maturity models could seek to complement maturity level descriptors with appropriate maturity level indicators examples in order to facilitate the ease of usage of those models.

- In contrast to the development of DfOSH-CMl tool (which took into account the determination of the relative importance (i.e. weights) of the capability attributes), several maturity models assume that the relevant key process areas carry the same weight of importance (e.g. Filho et al., 2010; Meng et al., 2011; Computer Integrated Construction Research Program, 2013; Kang et al., 2015; Langston and Ghanbaripour, 2016; Liang et al., 2016), which might not be the case. In view of this, researchers or CMM developers, when developing CMMs should seek to determine and incorporate the weights of key process areas.

\subsection{Limitations}

The study has some limitations which are highlighted below:

- The study does not provide an acceptable or adequate level of DfOSH capability maturity, which could be project dependent as capability should be appropriate/commensurate to the $\mathrm{OSH}$ challenges/issues/risks associated with a project. Thus some projects may require higher levels of capability maturity than others.

- The number of respondents used in expert group techniques such as Delphi is usually low thus potentially raising questions of generalisability. However, in the 
process of developing the DfOSH CMM, the number of experts that were involved in the Delphi technique (i.e. 32 experts in round 1, 30 experts in round 2 , and 28 experts in round 3 ) was adequate as it exceeded the recommended number of experts (i.e. 8-12) for applying Delphi technique (Hallowell and Gambatese, 2010). Furthermore, the qualification criteria used in recruiting experts were in line with guidance for the selection of experts for Delphi technique application (Hallowell and Gambatese, 2010) in order to ensure that the required knowledge and expertise on the subject was obtained. Thus, as recommended for expert group techniques, in applying the Delphi technique in this study, the focus was on depth of knowledge rather than breadth of participation. Furthermore, the use of multi-methods in the overall research design (i.e. expert focus group discussion, Delphi technique, a preliminary expert evaluation of the DfOSH-CMI tool and a subsequent main expert evaluation) involving several participants enhanced the validity of the study. Nonetheless, other researchers could adopt alternative methods (e.g. a large cross-sectional survey) in replicating this study.

- While available guidance on testing CMM (e.g. Salah et al. 2014) using expert evaluation does not specify a minimum number of experts, the size of experts (i.e. up to 16) used in the expert evaluation may be deemed to be small. Therefore future research could include further evaluation of the DfOSH-CMI tool by using a larger group of experts. This could be useful in receiving additional feedback in augmenting the practical utility of the tool.

- The study focussed on designers (i.e. organisations fulfilling design roles) and not the capability of the principal designer (PD) role, which is a new role introduced by the UK CDM 2015 (HSE, 2015c). The PD role is only required on projects with more than one contractor (HSE, 2015) and the PD is required to plan, manage, monitor and coordinate $\mathrm{OSH}$ during the pre-construction phase of a project.

- As decisions made by the researchers in the development of the tool (e.g. number of maturity levels used, the formulation of descriptors, and categorisation of the attributes into six thematic clusters) were made in a systematic manner (based on available guidance from relevant literature and information provided by expert participants), the developed DfOSH-CMI tool can be considered to be adequately robust and useful as indicated by the evaluation results. Nonetheless, other researchers could also consider alternative decisions in replicating this study to interrogate whether alternative outcomes or additional insights could emerge.

- While it has been established that organisational capability has an effect on the fulfilment of a function or performance (see Tassabehji and Moorhouse, 2008; Smits et al., 2016; Devece et al., 2017; Mahamadu et al., 2017), this study did not test the relationship between DfOSH capability (as assessed by the tool) and the level of performance/implementation of DfOSH.

Overall, the above commentary on the limitations of the study provide fertile grounds for further studies that could yield additional empirical realities to augment the usefulness of the DfOSH-CMI tool to construction industry stakeholders.

\section{References}


Aires, M. D. M., Gamez, M. C. R., and Gibb, A. G. F. (2010) Prevention through design: The European directives on construction workplace accidents. Safety Science, 48(2), pp. 248-258.

Akinade, O., Oyedele, L., Ajayi, S., Bilal, M., Alaka, H. A., Owolabi, H. and Arawomo, O. (2018) Designing out construction waste using BIM technology: Stakeholders' expectations for industry deployment. Journal of Cleaner Production, 180, pp. 375-385.

Akinade, O., Oyedele, L., Omoteso, K., Ajayi, S., Bilal, M., Owolabi, H., Alaka, H., Ayris, L. and Henry Looney, J. (2017) BIM-based deconstruction tool: Towards essential functionalities. International Journal of Sustainable Built Environment, 6 (1).pp. 260-271.

Ameyaw, E. E., Hu, Y., Shan, M., Chan, A. P. C. and Le, Y. (2016) Application of Delphi method in construction engineering and management research: $A$ quantitative perspective. Journal of Civil Engineering and Management, 22(8), pp. 991-1000.

Association for Project Management (2004) APM competence framework. Princes Risborough: Association for Project Management.

Austin, R. B., Pishdad-Bozorgi, P. and de la Garza, J. M. (2016) Identifying and prioritising best practices to achieve flash track projects. Journal of Construction Engineering and Management, 142(2), pp. 1-12.

Behm, M. (2005) Linking construction fatalities to the design for construction safety concept. Safety Science, 43(8), pp. 589-611.

Behm, M. and Schneller, A. (2013) Application of the Loughborough construction accident causation model: a framework for organizational learning. Constriction Management and Economics, 31 (6), pp. 580-595.

Behm, M., Culvenor, J. and Dixon, G. (2014) Development of safe design thinking among engineering students. Safety Science, 63, pp. 1-7.

Bloom, B.S. (ed.) (1956). Taxonomy of Educational Objectives, Handbook I: The Cognitive Domain. New York: Longman.

British Standard Institute (2013) Construction prequalification questionnaires, PAS91: 2013. London: BSI.

Bureau of Labor Statistics (2017) Census of fatal occupational injuries summary, 2016. Bureau of Labor Statistic. Available online at https://www.bls.gov/news.release/cfoi.nr0.htm [Accessed 5/01/2018].

Cameron, I. and Hare, B., (2008) Planning tools for integrating health and safety in construction. Construction Management and Economics, 26(9), pp. 899-909.

Carillion PIc (2013) Sustainability Report 2012. Carillion. Available online at http://sustainability2012.carillionplc.com/downloads/carillion-sr2012.pdf [Accessed 25/10/2016].

Chiesa, V., Coughlan, P. and Voss, C. (1996) Development of a technical innovation audit. Journal of Product Innovation Management, 13(2), pp. 105-136.

Computer Integrated Construction Research Program (2013) BIM Planning Guide for Facility Owners, Version 2.0. Pennsylvania: The Pennsylvania State University.

Constructing Excellence (2004) Effective teamwork - A best practice guide for the construction industry. Constructing Excellence.

Cooke, T. and Lingard, H. (2011) A retrospective analysis of work-related deaths in the Australian construction industry. In: Egbu, C. and Lou, E. C. W. (eds.) Proceeding of 27th Annual ARCOM Conference, 5-7 September 2011. Bristol, UK. Association of Researchers in Construction Management. 
Cooke, T., Lingard, H., Blismas, N. and Stranieri, A., (2008) The development and evaluation of a decision support tool for health and safety in construction design. Engineering, Construction and Architectural Management, 15(4), pp. 336-351.

Crosby, P. B. (1979) Quality is free: The art of making quality certain. New York: Penguin.

Curtis, B., Hefley, W. E., and Miller, S. (1995) People capability maturity model. Pittsburgh: Software Engineering Institute, Carnegie Mellon University.

Curtis, B., Hefley, W. E., and Miller, S. (2001) People capability maturity model Version 2.0. Pittsburgh: Software Engineering Institute, Carnegie Mellon University.

Deacon, J. (2009) Model-View-Controller (MVC) Architecture. Available online at http://www.rareparts.com/pdf/MVC.pdf [Accessed 15/05/2018].

Devece, C., Palacios, D., and Martinez-Simarro, D. (2017) Effect of information management capability on organizational performance. Service Business, 11(3), pp. 563-580.

European Commission (2015) User guide to SME definition. Luxemburg: Publications Office of the European Union.

Filho, A. P. G. and Waterson, P. (2018) Maturity models and safety culture: A critical review. Safety Science, 105, pp. 192-211.

Filho, A.P.G., Andrade, J.C.S. and Marinho, M.M.d.O., (2010) A safety culture maturity model for petrochemical companies in Brazil. Safety Science, 48 (5), pp. 615624.

Fraser, P., Farrukh, C. and Gregory, M. (2003) Managing product development Collaborations - A process maturity approach. Proceedings of the Institution of Mechanical Engineers, Part B: Journal of Engineering Manufacture, 217(11) pp. $1499-1519$.

Gambatese, J. A., Hinze, J. and Haas, C., (1997). Tool to Design for Construction Worker Safety. Journal of Architectural Engineering, 3(1), pp. 32-41.

Gangolells, M., Casals, M., Forcada, N., Roca, X., and Fuertes, A. (2010) Mitigating construction safety risks using prevention through design. Journal of Safety Research, 41(2), pp. 107-122.

Gibb, A.G.F., Haslam, R., Gyi, D.E., Hide, S. and Duff, R. (2006) What causes accidents? Proceedings of ICE- Civil Engineering, 159 (6), pp. 46-50.

Goh, Y. M. and Chua, S. (2016) Knowledge, attitude and practices for design for safety: A study on civil \& structural engineers. Accident Analysis and Prevention, 93, pp. 260-266.

Hadikusumo, B. and Rowlinson, S. (2012) Integration of virtually real construction model and design-for-safety-process database. Automation in Construction, 11(5), pp. 501-509.

Hadikusumo, B. H. W. and Rowlinson, S., (2004) Capturing Safety Knowledge Using Design-for-Safety-Process Tool. Journal of Construction Engineering and Management, 130(2), pp. 281-289.

Hadi-Vencheh, A. and Niazi-Motlagh, M. (2011) An improved voting analytic hierarchy process-data envelopment analysis methodology for suppliers selection. International Journal of Computer Integrated Manufacturing, 24(3), pp. 189-197.

Hallowell, M. R. and Gambatese, J. A. (2010) Qualitative research: Application of the Delphi method to CEM research. Journal of Construction Engineering and Management, 136(1), pp. 99-107.

HSE (2000) Keil Centre Offshore Technology Report 2000-049: Safety Culture Maturity Model. London: HSE Books. 
HSE (2007) Managing health and safety in construction - Construction (Design and Management) Regulations 2007 Approved Code of Practice. Bootle: Health and Safety Executive.

HSE (2015a) Historical picture - HISTINJ-Reported injuries in Great Britain by main industry and severity of injury, 1974 to latest year. HSE. Available online at http://www.hse.gov.uk/Statistics/tables/index.htm [Accessed 12/07/2016]

HSE (2015b) Health and safety in construction in Great Britain, 2014/15. HSE.

HSE (2015c) Managing health and safety in construction - Construction (Design and Management) Regulations 2015 Guidance L153. Norwich: HSE Books.

ILO (2012) Estimating the economic costs of occupational injuries and illnesses in developing countries: Essential information for decision-makers. ILO.

James, L.R., Demaree, R.G. and Wolf, G. (1984) Estimating within-group interrater reliability with and without response bias. Journal of Applied psychology, 69(1), pp. 85-98.

Kang, Y., O'Brien, W. J. and O'Connor, J. T. (2015) Information-Integration Maturity Model for the Capital Projects Industry. Journal of Management in Engineering, 31 (4), pp. 1-12

Kheni, N.A., Dainty, A.R.J., Gibb, A., (2008) Health and safety management in developing countries: a study of construction SMEs in Ghana. Construction Management and Economics, 26 (11), pp. 1159-1169.

Langston, C. and Ghanbaripour, A.N. 2016. A Management Maturity Model (MMM) for project-based organisational performance assessment. Construction Economics and Building, 16(4), pp. 68-85.

Liang, C., Lu, W., Rowlinson, S. Zhang, X. (2016) Development of a Multifunctional BIM Maturity Model. Journal of Construction Engineering and Management, 142 (11), pp. 1-9.

Liu, F-H. F. and Hai, H. L. (2005) The voting analytic hierarchy process method for selecting supplier. International Journal of Production Economics, 97(3), pp. 308317.

López-Arquillos, A., Rubio-Romero, J. and Martinez-Aires, M. (2015) Prevention through design (PtD). The importance of the concept in engineering and architecture university courses. Safety Science, 73, pp. 8-14.

Macgillivray, B. H., Sharp, J. V., Strutt, J. E., Hamilton, P. D. and Pollard, S. J. T. (2007) Benchmarking risk Management within the international water utility sector. Part I: Design of a capability maturity methodology. Journal of Risk Research, 10 (1), pp. 85-104.

Mahamadu, A-M., Mahdjoubi, L. and Booth, C. (2017) Critical BIM qualification criteria for construction pre-qualification and selection. Architectural Engineering and Design Management. 13(5), pp. 326-343.

Maier, A. M., Moultrie, J. and Clarkson, P. J. (2012) Assessing organizational capabilities: Reviewing and guiding the development of maturity grids. IEEE Transactions on Engineering Management, 59(1), pp. 138-159.

Manu, P., Ankrah, N., Proverbs, D. and Suresh, S. (2014) The health and safety impact of construction project features. Engineering Construction and Architectural Management, 21(1), pp. 65 - 93.

Manu, P., Mahamadu, A.-M., Phung, V. M., Nguyen, T. T., Ath, C., Heng, A. Y. T., and Kit, S. C. (2018). Health and safety management practices of contractors in South East Asia: A multi country study of Cambodia, Vietnam, and Malaysia. Safety Science, 107, pp. 188-201. 
Manu, P., Mahdjoubi, L., Gibb, A., and Behm, M. (2017) Briefing: New tool will help civil engineers meet CDM requirements to design for safety. Proceedings of the Institution of Civil Engineers - Civil Engineering, 170 (CE2), p. 55.

Manu, P., Poghosyan, A., Mahamadu, A., Mahdjoubi, L., Gibb, A, Behm, M. and Akinade, O. (2019) Design for occupational safety and health: Key attributes for organisational capability. Engineering, Construction and Architectural Management, DOI: 10.1108/ECAM-09-2018-0389.

McCuen, T. L., Suermann, P. C. and Krogulecki, M. J. (2012) Evaluating awardwinning BIM projects using the National Building Information Model Standard Capability Maturity Model. Journal of Management in Engineering. 28(2), pp. 224-230.

Meng, X., Sun, M. and Jones, R. (2011) Maturity model for supply chain relationships in Construction. Journal of Management in Engineering, 27 (2), pp. 97-105.

Network Rail (2015) CDM Note 002 - Principal designer's representative assessment template and guidance. Network Rail. Available online at https://safety.networkrail.co.uk/wp-content/uploads/2016/03/CDM-Note-002\%E2\%80\%93-Principal-Designer-Appointment.pdf [Accessed 31/08/2017].

Nussbaum, M. A. et al., (2009) Development of a decision support system for residential construction using panellised walls: Approach and preliminary results. Ergonomics, 52(1), pp. 87-103.

Office of Road and Rail and Health and Safety Laboratory (2017) RM3 - The risk management maturity model. Buxton: Health and Safety Laboratory.

Öney-YazıcI, E. and Dulaimi, M. F. (2015), "Understanding designing for construction safety: the interaction between confidence and attitude of designers and safety culture", Architectural Engineering and Design Management, 11(5), pp. 325337.ONS (2011) Construction statistics, No. 12, 2011 Edition. ONS.

ONS (2011) Construction statistics, no. 12, 2011 Edition. ONS.

Pane, E. S. and Sarong, R. (2015) Capability Maturity Model Integration (CMMI) for Optimizing Object-Oriented Analysis and Design (OOAD), Procedia Computer Science 72, pp. $40-48$.

Paulk, M.C., Chrissis, C., Weber, M.B. (1993) Capability maturity model, version 1.1. IEEE Software, 10 (4), pp. 18-27.

Poghosyan, A., Manu, P., Mahdjoubi, L., Gibb, A. G. F., Behm, M., and Mahamadu, A. M. (2018). Design for safety implementation factors: a literature review. Journal of Engineering, Design and Technology, 16(5), pp. 783-797.

Proença, D. and Borbinha, J. (2016) Maturity models for information systems - A state of the art. Procedia Computer Science, 100, pp. $1042-1049$.

Reenskaug, T. and Skaar, A. L. (1989) An environment for literate Smalltalk programming, Conference proceedings on Object-oriented programming systems languages and applications.

Rogers E. M. (2003) Diffusion of innovation, $5^{\text {th }}$ edn. New York: Free Press.

Sadeghi, L., Mathieu, L., Tricot, N. and Bassit, L. A., (2015) Developing a safety indicator to measure the safety level during design for safety. Safety Science, 80, pp. 252-263.

Salah, D., Paige, R. and Cairns, P. (2014) An evaluation template for expert review of maturity models. In: Jedlitschka, A., Kuvaja, P., Kuhrmann, M., Männistö, T., Münch, J. and Raatikainen, M. (eds.) Proceedings of 15th International Conference on Product-Focused Software Process Improvement, PROFES 2014, December 10-12, 2014, Helsinki, Finland. Springer 
Schulte, P. A., Rinehart, R., Okun, A., Geraci, C. L., and Heidel, D. S. (2008) National prevention through design (PtD) initiative. Journal of Safety Research, 39(2), pp. 115-121.

Sebastian, R. and van Berlo, L. (2010) Tool for benchmarking BIM performance of design, engineering and construction firms in The Netherlands. Architectural Engineering and Design Management, 6(4), pp. $254-263$.

Sharp J. V, Strutt, J. E., Busby, J. E. and Terry, E. (2002) Measurement of organisational maturity in designing safe offshore installations. Oslo: Offshore Marine and Arctic Engineering.

Simukonda, W., Manu, P., Mahamadu, A.-M., and Dziekonski, K. (2018). Occupational safety and health management in developing countries: a study of construction companies in Malawi. International Journal of Occupational Safety and Ergonomics, 1-16. DOI: 10.1080/10803548.2018.1482649.

Smits, W., van Buiten, M., and Hartmann, T. (2017) Yield-to-BIM: impacts of BIM maturity on project performance. Building Research \& Information, 45(3), pp. 336-346.

Strutt, J. E., Sharp, J. V., Terry, E. and Miles, R. (2006) Capability maturity models for offshore organisational management. Environment International, 32, pp.10941105.

Succar, B. (2009) Building information modelling maturity matrix. In: Underwood, J. and Isikdag, U. (Eds.) Handbook of Research on Building Information Modelling and Construction Informatics: Concepts and Technologies. Hersey: Information Science Reference.

Tassabehji, R., and Moorhouse, A. (2008) The changing role of procurement: Developing professional effectiveness. Journal of Purchasing and Supply Management, 14(1), pp. 55-68.

Toh, Y. Z., Goh, Y. M. and Guo, B. H. W. (2017) Knowledge, attitude, and practice of design for safety: multiple stakeholders in the Singapore construction industry. Journal of Construction Engineering and Management, 143(5), pp 1-11.

Waehrer, G. M., Dong, X. S., Miller, T., Haile, E. and Men, Y. (2007) Costs of occupational injuries in construction in the United States. Accident Analysis and Prevention, 39(6), pp. 1258-1266.

Weinstein, M., Gambatese, J., and Hecker, S. (2005) Can design improve construction safety?: Assessing the impact of a collaborative safety-in-design process. Journal of Construction Engineering Management, 131(10), pp. 1125-1134.

Willis, C. J and Rankin, J. H. (2012) The construction industry macro maturity model (CIM3): theoretical underpinnings, International Journal of Productivity and Performance Management, 15(2), pp. 87-116.

Workplace Safety and Health Institute (2013) Economic cost of work-related injuries and ill-health in Singapore. Workplace Safety and Health Institute. Available online at https://www.wshinstitute.sg/files/wshi/upload/cms/file/Economic\%20Cost\%20of\%20Workrelated\%20Injuries\%20and\%20III-health\%20in\%20Singapore.pdf [Accessed 21/07/2016]. 
Appendix: Evaluation Form

\begin{tabular}{|c|c|c|c|c|c|}
\hline \multirow[b]{2}{*}{ Assessment Criteria } & \multicolumn{5}{|c|}{ Level of Agreement } \\
\hline & $\begin{array}{c}\text { Strongly } \\
\text { Agree } \\
\text { (5) }\end{array}$ & $\begin{array}{l}\text { Agree } \\
(4)\end{array}$ & $\begin{array}{c}\text { Neither } \\
\text { Disagree } \\
\text { Nor Agree } \\
\text { (3) }\end{array}$ & $\begin{array}{l}\text { Disagree } \\
\text { (2) }\end{array}$ & $\begin{array}{c}\text { Strongly } \\
\text { Disagree } \\
\text { (1) }\end{array}$ \\
\hline \multicolumn{6}{|l|}{ Attributes } \\
\hline Attributes are relevant to DfOSH capability. & $\square$ & $\square$ & $\square$ & $\square$ & $\square$ \\
\hline Attributes cover all aspects of DfOSH capability. & $\square$ & $\square$ & $\square$ & $\square$ & $\square$ \\
\hline $\begin{array}{l}\text { Attributes are correctly assigned to their respective maturity } \\
\text { level. }\end{array}$ & $\square$ & $\square$ & $\square$ & $\square$ & $\square$ \\
\hline Attributes are clearly distinct. & $\square$ & $\square$ & $\square$ & $\square$ & $\square$ \\
\hline \multicolumn{6}{|l|}{ Maturity Levels } \\
\hline $\begin{array}{l}\text { The maturity levels sufficiently represent maturation in the } \\
\text { attributes. }\end{array}$ & $\square$ & $\square$ & $\square$ & $\square$ & $\square$ \\
\hline $\begin{array}{l}\text { There is no overlap detected between descriptions of } \\
\text { maturity levels. }\end{array}$ & $\square$ & $\square$ & $\square$ & $\square$ & $\square$ \\
\hline \multicolumn{6}{|l|}{ Ease of Understanding } \\
\hline The maturity levels are understandable & $\square$ & $\square$ & $\square$ & $\square$ & $\square$ \\
\hline The indicator examples are understandable & $\square$ & $\square$ & $\square$ & $\square$ & $\square$ \\
\hline The results are understandable & $\square$ & $\square$ & $\square$ & $\square$ & $\square$ \\
\hline $\begin{array}{l}\text { The documentation (i.e. information on the webpages e.g. } \\
\text { home page, etc.) is understandable }\end{array}$ & $\square$ & $\square$ & $\square$ & $\square$ & $\square$ \\
\hline \multicolumn{6}{|l|}{ Ease of Use } \\
\hline $\begin{array}{l}\text { The scoring scheme (i.e. drop-down options for maturity levels) } \\
\text { is easy to use }\end{array}$ & $\square$ & $\square$ & $\square$ & $\square$ & $\square$ \\
\hline $\begin{array}{l}\text { The indicator examples make the assessment easy to } \\
\text { undertake }\end{array}$ & $\square$ & $\square$ & $\square$ & $\square$ & $\square$ \\
\hline The online navigation of DfOSH-CMI is easy & $\square$ & $\square$ & $\square$ & $\square$ & $\square$ \\
\hline $\begin{array}{l}\text { The introductory video helped me to understand how to use } \\
\text { the tool }\end{array}$ & $\square$ & $\square$ & $\square$ & $\square$ & $\square$ \\
\hline \multicolumn{6}{|l|}{ Usefulness and Practicality } \\
\hline DfOSH-CMI is useful for assessing DfOSH capability & $\square$ & $\square$ & $\square$ & $\square$ & $\square$ \\
\hline DfOSH-CMI is practical for use in industry & $\square$ & $\square$ & $\square$ & $\square$ & $\square$ \\
\hline
\end{tabular}

